\section{Isolation and Characterization of Exosomes from Cell Culture Supernatants and Biological Fluids}

Exosomes are small vesicles secreted by most cell types in culture. Exosomes form intracellularly by inward budding of the limiting membrane of endocytic compartments, leading to vesicle-containing endosomes, called multivesicular bodies (MVBs). MVBs eventually fuse with the plasma membrane, thus releasing their internal vesicles (i.e., exosomes) into the extracellular medium. What, then, may the physiological function of exosomes be? On one hand, exosome secretion could be a function per se, e.g., exosome secretion by reticulocytes allows the elimination of proteins such as transferrin receptor or integrins, which are useless in differentiated red blood cells (Pan et al., 1985; Vidal et al., 1997). On the other hand, exosomes could be involved in intercellular communication, allowing exchange of proteins and lipids between the exosome-producing cells and target cells. Such a function has been exemplified in the immune system where exosomes allow exchange of antigen or major histocompatibility complex (MHC)-peptide complexes between antigen-bearing cells and antigen-presenting cells (e.g., dendritic cells; Wolfers et al., 2001; Andre et al., 2002, 2004; Théry et al., 2002). Nevertheless, the physiological functions of exosomes remain a matter of debate.

The purpose of this unit is to give simple and reliable methods for purifying and characterizing exosomes. Cell culture supernatants (conditioned media; CM) contain several types of shed membrane fragments and vesicles; therefore, before performing any functional analysis, it is critical to ensure that the purified vesicles are exosomes and not other contaminating material. The first part of this unit describes the most common protocols used to purify exosomes from cell culture conditioned media or from physiological fluids, and the second part describes different methods for characterizing and assessing the purity of the isolated exosomes.

Exosomes have been successfully purified from cell culture conditioned medium or bodily fluids. Support Protocols 1 and 2 provide all details and precautions to take in collecting materials from which exosomes will be purified. Starting from this material, the original and most commonly used protocol for exosome purification (Raposo et al., 1996) is described in Basic Protocol 1. It involves several centrifugation and ultracentrifugation steps. In some cases, the first centrifugation steps can be replaced by a single filtration step: this option is described in an Alternate Protocol. A slightly modified version of Basic Protocol 1, designed for purifying exosomes from viscous fluids (e.g., plasma) is described in Basic Protocol 2. An extra purification step that provides extremely pure exosomes can be added to these protocols, and is described in Support Protocol 3. A different purification procedure, involving trapping exosomes on beads bearing an antibody specific for exosomal surface molecules, has more recently been described (Clayton et al., 2001) and is provided in Basic Protocol 3. It is easy to use and useful for rough characterization of exosomes, but it is not intended for purification of large amounts of exosomes. An additional new method for purifying exosomes by ultrafiltration instead of ultracentrifugation is not described in this unit. This method employs ultrafiltration cartridges and pumps and is especially useful for purifying exosomes from large volumes ( $>1$ liter) of conditioned medium. It is suitable for clinical applications of purified exosomes, but it is not the easiest option for laboratory applications. Interested readers should see Lamparski et al. (2002) for details.

Contributed by Clotilde Théry, Aled Clayton, Sebastian Amigorena, and Graça Raposo

Current Protocols in Cell Biology (2006) 3.22.1-3.22.29

Copyright (C) 2006 by John Wiley \& Sons, Inc.
UNIT 3.22

Subcellular

Fractionation and Isolation of Organelles

3.22.1

Supplement 30 
Identification of membrane vesicles as exosomes requires morphological analysis. Given their small size (50 to $90 \mathrm{~nm}$ ), exosomes can be visualized only with an electron microscope; thus, evaluation of the purity of exosome preparations as well as their characterization should be determined by electron microscopy (see Support Protocols 4, 5, and 6). Separation of exosomes by SDS-PAGE, followed by Coomassie blue staining of all exosomal proteins also gives an idea of the quality of the exosome preparation: exosomes should contain a large number of proteins, i.e., at least a few dozen, many of which are distinct from the proteins detected in whole cell lysates. Further characterization involves analysis of the physical properties of exosomes on a continuous sucrose gradient (Support Protocol 7) and of protein quantity (Support Protocol 9) and composition by immunoblotting (Support Protocol 8) and FACS analysis (Support Protocol 10).

BASIC PROTOCOL 1

Isolation and Characterization of Exosomes

3.22.2

\section{PURIFICATION OF EXOSOMES BY DIFFERENTIAL} ULTRACENTRIFUGATION

The general idea of exosome purification by ultracentrifugation is depicted in Figure 3.22.1. The first steps are designed to eliminate large dead cells and large cell debris by successive centrifugations at increasing speeds (steps 1 to 5 below). At each of these steps, the pellet is thrown away, and the supernatant is used for the following step (Fig. 3.22.1). The final supernatant is then ultracentrifuged at $100,000 \times g$ to pellet the small vesicles that correspond to exosomes. The pellet is washed in a large volume of PBS, to eliminate contaminating proteins, and centrifuged one last time at the same high speed.

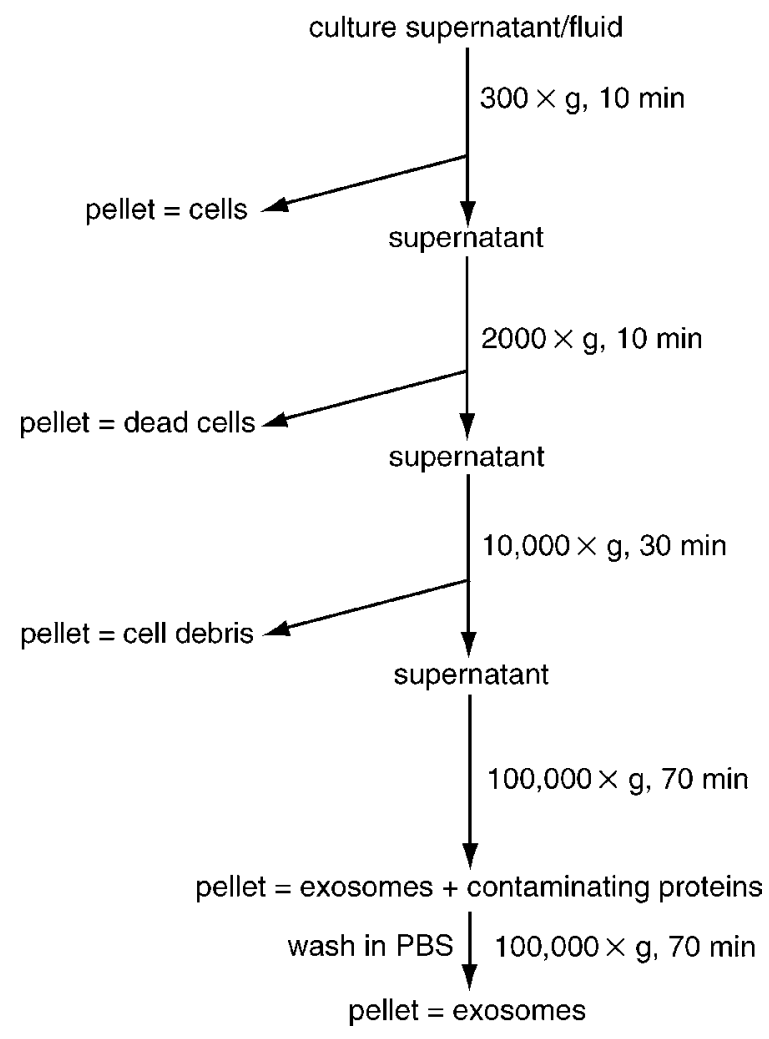

Figure 3.22.1 Flow chart for the exosome purification procedure based on differential ultracentrifugation. The speed and length of each centrifugation are indicated to the right of the arrows. After each of the first three centrifugations, pellets (cells, dead cells, cell debris) are discarded, and the supernatant is kept for the next step. In contrast, after the two $100,000 \times g$ centrifugations, pellets (exosomes + contaminant proteins, exosomes) are kept, and supernatants are discarded. 
Table 3.22.1 Ultracentrifuge and Rotor Information for Exosome Purification

\begin{tabular}{|c|c|c|c|c|c|c|c|}
\hline $\begin{array}{l}\text { Rotor } \\
\text { (Beckman) }\end{array}$ & $\begin{array}{c}\text { Tubes } \\
\text { (Beckman) }\end{array}$ & $\begin{array}{c}\text { Max } \\
\text { vol/tube } \\
(\mathrm{ml})\end{array}$ & $\begin{array}{c}\text { Max } \\
\text { vol/rotor } \\
(\mathrm{ml})\end{array}$ & $\begin{array}{l}\text { rpm for } \\
10,000 \times g\end{array}$ & $\begin{array}{l}\text { rpm for } \\
12,000 \times g\end{array}$ & $\begin{array}{l}\text { rpm for } \\
100,000 \times g\end{array}$ & $\begin{array}{l}\text { rpm for } \\
110,000 \times g\end{array}$ \\
\hline $\begin{array}{l}\text { SW } 41 \text { or } 40 \\
\text { (swinging } \\
\text { bucket) }\end{array}$ & Polyallomer & 12 & 72 & 7,500 & 8,200 & 24,000 & 25,000 \\
\hline $\begin{array}{l}\text { SW } 28 \text { or } 32 \\
\text { (swinging } \\
\text { bucket) }\end{array}$ & Polyallomer & 30 & 180 & 7,500 & 8,200 & 24,000 & 25,000 \\
\hline $70 \mathrm{Ti}$ & $\begin{array}{l}\text { Polycarbonate } \\
\text { bottle }\end{array}$ & 22 & 180 & 10,000 & 11,000 & 31,000 & 32,000 \\
\hline $45 \mathrm{Ti}$ & $\begin{array}{l}\text { Polycarbonate } \\
\text { bottle }\end{array}$ & 68 & 400 & 9,000 & 10,000 & 30,000 & 31,000 \\
\hline TLA-100.3 & Thick-walled & 3 & 18 & 13,000 & 15,000 & 43,000 & 45,000 \\
\hline TLA-110 & polycarbonate & 5 & 40 & & & & \\
\hline
\end{tabular}

\section{Materials}

Conditioned medium (Support Protocol 1, step 5), cleared

Phosphate-buffered saline (PBS; APPENDIX 2A)

Tris-buffered saline (TBS; APPENDIX 2A), optional

Refrigerated centrifuge

50-ml polypropylene centrifuge tubes

Ultracentrifuge and fixed-angle or swinging-bucket rotor (see Table 3.22.1)

Polyallomer tubes or polycarbonate bottles, appropriate for the ultracentrifuge rotor (see Table 3.22.1)

Micropipettor (e.g., Pipetman)

Tabletop ultracentrifuge (e.g., Beckman TL-100)

$-80^{\circ} \mathrm{C}$ freezer

NOTE: All centrifugations should be performed at $4{ }^{\circ} \mathrm{C}$.

NOTE: It is only necessary to use sterile equipment if the final use of exosomes is going to require sterility (e.g., functional in vivo or in vitro assay). If only biochemical analyses will be performed (e.g., immunoblot, proteomics, FACS analysis), very clean, but not necessarily sterile, tubes are required.

NOTE: If sterility is required, sterile centrifuge and ultracentrifuge tubes must be used, and all steps up to the time when CM-containing tubes or tube holders are closed must be performed in a tissue culture hood. To sterilize ultracentrifuge tubes, wash the clean tubes and their lids briefly in 70\% ethanol, rinse twice in sterile PBS, pour PBS off, and drain the remaining drops of PBS with a pipet before use. The rotor lid (45Ti rotor) or the lid for each tube holder (SW41, SW28 rotors) must also be cleaned with 70\% ethanol before closing the rotors.

\section{Remove cells, dead cells, and cellular debris}

1. Transfer the cleared, conditioned medium to 50-ml centrifuge tubes.

2. Centrifuge $20 \mathrm{~min}$ at $2,000 \times g, 4^{\circ} \mathrm{C}$.

3. Pipet off the supernatant, and transfer it to polyallomer tubes or polycarbonate bottles appropriate for the ultracentrifugation rotor to be used.

Subcellular

Fractionation and Isolation of Organelles

3.22.3 
Ensure that none of the pellet is collected and contaminates the supernatant. Use a pipet, rather than pouring off the supernatant, and leave behind half a centimeter of liquid above the pellet.

4. Mark one side of each ultracentrifuge tube with a waterproof marker, orient the tube in the rotor with the mark facing up, and centrifuge $30 \mathrm{~min}$ at $10,000 \times \mathrm{g}, 4^{\circ} \mathrm{C}$ (see Table 3.22.1).

The mark is a reference for the location of a pellet at the end of the centrifugation.

\section{Collect exosome fraction}

5. Transfer the supernatant to a fresh tube or bottle the same size as in step 3.

Ensure that none of the pellet is collected and contaminates the supernatant.

There will probably not be a visible pellet at this step. For swinging-bucket rotors, the pellet is at the bottom of the tube. For fixed-angle rotors, the pellet is on the side of the tube facing up (marked by the marker pen) near the bottom of the tube.

When removing the supernatant with the pipet, hold the tube at an angle, so that the pellet is always covered with supernatant, and stop removing supernatant when half a centimeter of liquid is still covering the pellet.

6. Centrifuge at least $70 \mathrm{~min}$ at $100,000 \times g, 4^{\circ} \mathrm{C}$.

For this high-speed centrifugation, all tubes should be at least three-quarters full. If one of the tubes is not three-quarters full, add PBS.

Centrifugation time is calculated to allow a full hour at 100,000 $\times$ g, i.e., $\sim 10 \mathrm{~min}$ for the centrifuge to reach $100,000 \times \mathrm{g}$ plus $1 \mathrm{hr}$ at the final speed. A longer time (up to $3 \mathrm{hr}$ ) will not damage the exosomes.

7. Remove the supernatant completely.

For fixed-angle rotors, at this step, pour off the supernatant rather than use a pipet.

For swinging-bucket rotors, remove the supernatant with a pipet and leave $2 \mathrm{~mm}$ of supernatant above the pellet.

\section{Wash exosomes}

8. Resuspend the pellet in each tube in $1 \mathrm{ml}$ PBS, using a micropipettor. Pool the resuspended pellets from all the tubes containing materials from the same cells in a single centrifuge tube. Then add PBS to fill the tube completely.

There will probably not be a visible pellet at this step. For fixed-angle rotors, resuspend by flushing up and down where the pellet should be (upper side of the tube, towards the bottom). For swinging-bucket rotors, flush the bottom of the tube.

9. Centrifuge $1 \mathrm{hr}$ at $100,000 \times g, 4^{\circ} \mathrm{C}$.

10. Remove the supernatant as completely as possible. For fixed-angle rotors, pour off the supernatant, keep the tube upside down, and aspirate the remaining liquid on the sides and the mouth of the tube with a micropipettor. Proceed to step 11a or step $11 b$

11a. To resuspend the pellet (i.e., exosomes): Add a small volume (50 to $100 \mu \mathrm{l})$ of PBS or TBS and resuspend.

If the final volume of exosomes is too large (>1/2000 of the initial volume of conditioned medium) or if there was no visible pellet at step 10, use step 11 instead.

11b. To concentrate the exosome preparation: Centrifuge the supernatant (step 10) $1 \mathrm{hr}$ at $100,000 \times g, 4{ }^{\circ} \mathrm{C}$ in a tabletop ultracentrifuge, using a TLA-100.3 rotor and the corresponding thick-walled polycarbonate tubes. Remove most of the PBS above the visible pellet and resuspend exosomes in 20 to $50 \mu$ of fresh PBS. 
12. Store exosomes up to 1 year at $-80^{\circ} \mathrm{C}$ in $100-\mu \mathrm{l}$ aliquots. Avoid repeated freezing and thawing.

\section{ELIMINATION OF LARGE CELL DEBRIS AND MEMBRANES BY FILTRATION}

For some cells (e.g., mouse dendritic cells) it is possible to replace steps 1 to 6 of Basic Protocol 1 with a single filtration step using a $0.22-\mu \mathrm{m}$ filter; this will eliminate dead cells and large debris while keeping small membranes for further purification by ultracentrifugation. To determine whether this Alternate Protocol can be used, perform Basic Protocol 1 once using the same volume of conditioned medium obtained from the same cells at the same time in parallel with this protocol, to compare the yields and the quality of exosomes by electron microscopy and immunoblotting (Support Protocols 4 , $5,6,7,8,9$, and 10 ), to ensure that the exosome preparations are identical.

\section{Materials (also see Basic Protocol 1)}

$0.22-\mu \mathrm{m}$ filter sterilization device (e.g., Steritop; Millipore)

100-ml to 1-liter glass bottle, sterile

1. Filter sterilize the conditioned medium by passing through a vacuum-connected $0.22-\mu \mathrm{m}$ filter on top of a sterile bottle, using a vacuum.

2. Store the filtered supernatant up to 1 week at $4{ }^{\circ} \mathrm{C}$ before proceeding to exosome purification (Basic Protocol 1, steps 8 to 12).

\section{COLLECTING CULTURE SUPERNATANTS FOR EXOSOME PURIFICATION}

The exosome-containing conditioned medium from cultured cells is used as the starting material for exosome purification. Total cell lysate of the cells that produce the conditioned medium is prepared at the same time and is used later in parallel with exosomes for immunoblot analysis (Support Protocol 8).

\section{Materials}

Cells in culture (UNIT 1.1)

Exosome-production medium (Support Protocol 2)

Phosphate-buffered saline (PBS; APPENDIX 2A)

Cell lysis buffer (see recipe)

Refrigerated centrifuge

50-ml polypropylene centrifuge tubes

$500-\mathrm{ml}$ or 1-liter glass bottle, sterile

$1.5-\mathrm{ml}$ microcentrifuge tubes

Additional materials for growing and counting cells in culture (UNIT 1.1) and clearing conditioned medium by filtration (Alternate Protocol; optional)

\section{Collect and clear conditioned medium}

1. Grow cells of interest under the usual conditions (see UNIT 1.1) until they reach $70 \%$ to $80 \%$ confluency for adherent cells, or $60 \%$ to $70 \%$ of their maximum concentration for cells grown in suspension.

Use as many cells as necessary to produce at least 70-ml of conditioned medium (i.e., a minimum of seven 10-cm dishes and up to twenty $15-\mathrm{cm}$ dishes); it is always better to purify exosomes from large volumes of conditioned medium because the yield of the purification procedure increases with the starting volume.
ALTERNATE PROTOCOL

SUPPORT

PROTOCOL 1

Subcellular

Fractionation and Isolation of Organelles

3.22.5

Supplement 31 
2a. For adherent cells: Remove the culture medium, and replace it with a similar volume of exosome-production medium.

2b. For cells in suspension: centrifuge cells $10 \mathrm{~min}$ at $300 \times g, 4^{\circ} \mathrm{C}$, pour off the supernatant, and resuspend cells in the same volume of exosome-production medium.

3. Return the cells to the incubator for 24 to $48 \mathrm{hr}$.

Cells that grow fast may be overconfluent and start dying after $48 \mathrm{hr}$. In this case, take the conditioned medium after $24 \mathrm{hr}$.

Cells that are very sensitive may not like growing in exosome production medium or in FBS-free medium. In this case, take the supernatant after $24 \mathrm{hr}$. For instance, dendritic cells tend to mature spontaneously if kept for $48 \mathrm{hr}$ in exosome-production medium.

4a. To clear conditioned medium from adherent cells: Collect the conditioned medium with a pipet and transfer to 50-ml polypropylene centrifuge tubes. Centrifuge cells 10 min at $300 \times g, 4^{\circ} \mathrm{C}$, and collect the conditioned medium with a pipet.

4b. To clear conditioned medium from cells in suspension: Centrifuge cells $10 \mathrm{~min}$ at $300 \times g, 4^{\circ} \mathrm{C}$, and collect the conditioned medium with a pipet and transfer to 50-ml polypropylene centrifuge tubes.

The centrifugations will pellet the cells from suspension cultures or remove the large dead cells from adherent cultures.

5. Transfer the conditioned medium to a sterile glass bottle. Pool supernatants from all dishes or flasks containing the same cell type into a single bottle and store up to 1 week at $4^{\circ} \mathrm{C}$.

Once supernatant is collected, the authors strongly recommend proceeding with exosome purification (Basic Protocol 1, Basic Protocol 3, or Alternate Protocol) as soon as possible. Keeping the supernatant at $4^{\circ} \mathrm{C}$ for up to a week may lead to loss of some exosomes (C. Théry and S. Amigorena, unpub. observ.). Alternatively, some investigators have successfully isolated exosomes from supernatants kept at $-80^{\circ} \mathrm{C}$ for several months, but this also probably leads to exosome loss and should be avoided.

\section{Prepare total cell lysate}

6a. To collect adherent cells: Trypsinize adherent cells from one to two dishes and count cells with a hemacytometer (see UNIT 1.1).

6b. To collect cells in suspension: Use cells from the pellet remaining in the tube after step 4b. Resuspend and count cells with a hemacytometer (see UNIT 1.1).

7. Put $1-5 \times 10^{7}$ cells in a microcentrifuge tube. Centrifuge $5 \mathrm{~min}$ at $300 \times \mathrm{g}, 4^{\circ} \mathrm{C}$, discard supernatant, and resuspend the cell pellet in 1-ml of PBS. Centrifuge and repeat the PBS wash and centrifugation.

8. Add $200-\mu \mathrm{l}$ (for $1 \times 10^{7}$ cells) or 1 -ml (for $5 \times 10^{7}$ cells) of cell lysis buffer to the cell pellet and incubate 20 min on ice, vortexing at the beginning and end of the incubation.

9. Centrifuge $20 \mathrm{~min}$ at $20,000 \times g, 4^{\circ} \mathrm{C}$. Collect the supernatant in a fresh microcentrifuge tube. Store up to 6 months at $-20^{\circ} \mathrm{C}$.

The total cell lysate is used in parallel with exosomes for immunoblot analysis (Support Protocol 8).

Isolation and Characterization of Exosomes 
Exosomes are present in the serum generally used for tissue culture. To avoid contamina-

tion by these exosomes, culture medium used to grow cells for conditioned media from which the cell-derived exosomes will be purified must be depleted of the contaminating exosomes. There are two options for depleting medium of serum-derived exosomes: (1) if the cells grow in the absence of serum, exosome production-medium can be the basal culture medium, supplemented with all the nutrients and antibiotics, but no fetal bovine serum (FBS). If the cells need some proteins to survive, $1 \%(\mathrm{w} / \mathrm{v})$ bovine serum albumin (BSA) can be added instead of FBS. (2) If the cells do not survive in serum-free conditions, predeplete the FBS-derived exosomes from FBS-containing medium following this protocol to obtain FBS-exosome-free, exosome-production medium.

\section{Materials}

Culture medium complete with required nutrients (e.g., antibiotics, L-glutamine, HEPES, 2-mercaptoethanol, FBS

Ultracentrifuge and fixed-angle or swinging-bucket rotor (see Table 3.22.1)

Polyallomer tubes or polycarbonate bottles, appropriate for the ultracentrifuge rotor (see Table 3.22.1)

$0.22-\mu \mathrm{m}$ filter-sterilization device (e.g., Steritop; Millipore)

100-ml to 1-liter glass bottle, sterile

1. Prepare medium supplemented with all nutrients, plus $20 \%$ (v/v) FBS.

2. Centrifuge the medium overnight at $100,000 \times g, 4^{\circ} \mathrm{C}$.

Follow the same general instructions for centrifugation as explained in the exosome purification section; . i.e., mark a side of each tube with a waterproof marker, and orient the tubes in the centrifuge with mark facing up, indicating where to look for a pellet at the end of the centrifugation.

If using reusable centrifuge tubes, keep a specific batch of centrifuge tubes for medium depletion, and another different batch for exosome purification to avoid potential contamination with serum endosomes.

3. Filter sterilize the supernatant (i.e., depleted medium) by pouring the contents of each tube into a vacuum-connected $0.22-\mu \mathrm{m}$ filter on top of a sterile bottle.

Keep an eye on the pellet (on the marked side of the tube), to make sure that it does not become loose. If it does, stop pouring and throw away the medium remaining in the tube.

4. Dilute the depleted medium with medium supplemented with all the nutrients and antibiotics, but no FBS, in order to reach the final FBS concentration required to make the exosome production medium.

For instance, if the cells are normally cultured in $10 \%$ FBS, dilute 1 vol depleted medium with 1 vol FBS-free medium.

Depleting medium with $20 \%$ FBS allows depletion of a large volume of culture medium in a single round of centrifugation.

Do not deplete pure FBS because the viscosity of pure FBS will cause elimination of many proteins and factors, which will pellet as aggregates. The cells may not like it!

5. Store exosome-depleted medium after step 4 (sterilized, but not diluted) or step 5 (sterilized and diluted) up to 4 weeks at $4^{\circ} \mathrm{C}$.

Subcellular

Fractionation and Isolation of Organelles

3.22.7

Supplement 30 
BASIC

PROTOCOL 2
SUPPORT PROTOCOL 3

Isolation and Characterization of Exosomes

\section{PURIFYING EXOSOMES FROM VISCOUS FLUIDS}

To purify exosomes from bodily fluids (e.g., urine, broncho-alveolar lavage, serum, plasma, tumor ascites), simply collect the fluid by the usual means. Store up to 5 days at $4{ }^{\circ} \mathrm{C}$ in a glass bottle until proceeding with exosome purification.

The principle for exosome purification is the same as when starting from tissue culture conditioned media, but because of the viscosity of some fluids it is necessary to dilute them, and to increase the speed and lengths of centrifugations. This protocol has been used in the authors' laboratories for purification of exosomes from human plasma (Caby et al., 2005).

All precautions indicated in Basic Protocol 1 apply to this protocol as well.

\section{Materials}

Fluid (e.g., plasma: separate from blood cells by Ficoll centrifugation; lymph, serum, urine, bronchiolar lavage, or tumor ascites)

Phosphate-buffered saline (PBS; APPENDIX 2A)

Refrigerated centrifuge

50-ml polypropylene centrifuge tubes

$0.22-\mu \mathrm{m}$ filter device (e.g., Steritop, Millipore)

Ultracentrifuge and fixed-angle or swinging-bucket rotor (see Table 3.22.1)

Polyallomer tubes or polycarbonate bottles, appropriate for the ultracentrifuge rotor (see Table 3.22.1)

NOTE: All centrifugations should be performed at $4{ }^{\circ} \mathrm{C}$.

1. Dilute fluid with an equal volume of PBS. Transfer diluted fluid in 50-ml tubes. Centrifuge $30 \mathrm{~min}$ at $2,000 \times g, 4^{\circ} \mathrm{C}$.

2. Carefully transfer supernatant to ultracentrifuge tubes or bottles without pellet contamination (see Basic Protocol 1, step 3 annotation). Centrifuge $45 \mathrm{~min}$ at $12,000 \times g, 4^{\circ} \mathrm{C}$.

3. Carefully transfer supernatant to ultracentrifuge tubes or bottles (See Table 3.22.1 for tubes to choose according to the volume of fluid handled.). Centrifuge $2 \mathrm{hr}$ at $110,000 \times g, 4^{\circ} \mathrm{C}$.

4. Resuspend pellets in $1 \mathrm{ml}$ PBS and pool them in one of the tubes. Fill the tube with PBS to dilute the resuspension in a large volume.

5. Filter the suspension through a $0.22-\mu \mathrm{m}$ filter, and collect in a fresh ultracentrifuge tube or bottle.

6. Centrifuge $70 \mathrm{~min}$ at $110,000 \times g, 4^{\circ} \mathrm{C}$. Pour off the supernatant.

7. Resuspend the pellet in $1 \mathrm{ml}$ PBS, and then fill the tube with PBS. Centrifuge 70 $\min$ at $110,000 \times g, 4^{\circ} \mathrm{C}$. Pour off the supernatant.

8. Resuspend pellet in 50 to $200 \mu \mathrm{lBS}$. Store up to 1 year at $-80^{\circ} \mathrm{C}$.

\section{PREPARATION OF EXOSOMES ON A 30\% SUCROSE CUSHION}

Although Basic Protocols 1 and 2 provide reasonably pure exosomes, for some applications it may be advisable to include an extra purification step using a sucrose cushion. This step eliminates more contaminants, such as proteins nonspecifically associated with exosomes, or large protein aggregates, which are sedimented by centrifugation but do not float on a sucrose gradient.

\subsection{8}


Partially purified exosome pellet (Basic Protocol 1, step 10 or Basic Protocol 2, step 7)

Phosphate-buffered saline (PBS; APPENDIX 2A)

Tris/sucrose $/ \mathrm{D}_{2} \mathrm{O}$ solution (see recipe)

Ultracentrifuge with SW 28 and 45 Ti rotors

Polyallomer tubes appropriate for the SW 28 rotor (Table 3.22.1)

Thick-walled polycarbonate tubes appropriate for the 45 Ti rotor (Table 3.22.1)

5-ml syringe

$18-\mathrm{G}$ needle

NOTE: All centrifugations should be performed at $4{ }^{\circ} \mathrm{C}$.

1. Resuspend partially purified exosome pellet in $25 \mathrm{ml} \mathrm{PBS}$ total.

2. Load $4 \mathrm{ml}$ of Tris/sucrose/ $\mathrm{D}_{2} \mathrm{O}$ solution at the bottom of a SW 28 tube, to make a cushion.

3. Add the diluted exosomes gently above the sucrose cushion without disturbing the interface. Centrifuge $75 \mathrm{~min}$ at $100,000 \times g, 4^{\circ} \mathrm{C}$.

4. With a 5-ml syringe fitted with an $18-\mathrm{G}$ needle, collect $\sim 3.5 \mathrm{ml}$ of the Tris/sucrose $/ \mathrm{D}_{2} \mathrm{O}$ cushion, which now contains exosomes, from the side of the tube.

5. Transfer the exosomes to a fresh ultracentrifuge tube. Dilute exosomes to $60 \mathrm{ml}$ with PBS. Centrifuge $70 \mathrm{~min}$ at $100,000 \times g, 4^{\circ} \mathrm{C}$, in a 45 Ti rotor.

6. Resuspend the pellet in 50 to $100 \mu \mathrm{PBS}$.

\section{PURIFICATION OF EXOSOMES BY IMMUNOISOLATION}

A simple and rapid method, suitable for the routine isolation and analysis of exosomes, is based upon immuno-magnetic extraction of exosomes bearing human MHC Class II molecules as described by Clayton et al. (2001). (See Table 3.22.2 for exosome markers that are not immune or MHC molecules.). This method has been used by the authors and others (Rabesandratana et al., 1998; Wubbolts et al., 2003; Caby et al., 2005) using magnetic beads coated with antibodies directed against proteins exposed on exosomal membranes. It is, therefore, a mode of isolating exosomes without the need for ultracentrifugation. Furthermore, this method demonstrates colocalization of the protein recognized by the antibody-coated beads with other identified proteins, strengthening the evidence that the analysis is that of exosomes and not, for example, soluble contaminating proteins present in the exosome preparation.

There are several advantages and some disadvantages to this approach. The bead-exosome complexes can be analyzed by flow cytometry, using fluorophore-conjugated antibodies; this facilitates a rapid semiquantitative characterization of the exosome surface phenotype. Alternatively, bead-exosome complexes can be incubated in SDS sample buffer and analyzed by immunoblot (Support Protocol 8). In addition, the loaded beads can be processed for electron microscopy, which allows investigation of the morphology of the adsorbed membranes. Given their size, beads can only be observed after sectioning, which can be accomplished with standard electron microscopy methods such as resin embedding and ultrathin sectioning or, preferably, ultracryomicrotomy to avoid dehydration steps (Raposo et al., 1997). Do not use Support Protocols 4 and 5 for electron microscopy of exosome-bead complexes.

BASIC

PROTOCOL 3

Subcellular

Fractionation and Isolation of Organelles

3.22.9

Supplement 30 
The choice of exosome marker for immobilization is a key issue. For MHC Class IIpositive cells, the use of beads precoated with a pan class II-specific antibody is ideal. However, this marker is unsuitable for exosome isolation from non antigen-presenting cells which are MHC class II-negative. In theory, a good candidate marker would be MHC Class I molecules expressed on most if not all exosomes. Unfortunately, MHC class I molecules are also shed from the plasma membrane as a soluble molecule, especially in certain cancerous cells, so that the MHC class I-capturing antibody on the bead surface captures soluble class I as well as exosomally expressed class I molecules, significantly reducing the efficiency of exosome capture. Some suggested alternative exosome-capture molecules include members of the tetraspanin family such as CD81 or CD63, for MHC class II-negative cells (Table 3.22.2). Dynal products (available now from Invitrogen) provide naked beads for coating with antibodies of choice. There are at least 2 types: M-450 Epoxy and M-450 Tosylactivated. Other manufacturers make beads of a similar size, which may also be suitable.

Although selecting exosomes from a conditioned medium based on chosen exosomeexpressed proteins is an advantage in several ways, it is important to be aware that this approach may isolate only a subpopulation of marker-positive exosomes, so that subsequent analysis does not reflect the exosome population as a whole. Immunoisolation is not appropriate for purification of large amounts of exosomes. Finally, once captured on beads, exosomes retaining full functionality may not be successfully eluted from the bead surface.

\section{Materials}

Conditioned medium from cultured cells (Support Protocol 1)

Phosphate-buffered saline (PBS; APPENDIX 2A) containing $3 \mathrm{mg} / \mathrm{ml}$ bovine serum albumin (BSA), filter sterilized and stored up to 1 month at $4^{\circ} \mathrm{C}$

50-ml centrifuge tubes, sterile

Refrigerated centrifuge

4.5 $\mu \mathrm{M}$ paramagnetic Dynabeads M-450 (Dynal), ready-coated with antibodies (e.g., anti-human MHC II)

Magnet (Dynal)

Test tube rolling machine holding 50-ml tubes

1. Transfer the conditioned medium (Support Protocol 1, step 5) to 50-ml centrifuge tubes. Centrifuge $10 \mathrm{~min}$ at $2,000 \times g, 4^{\circ} \mathrm{C}$.

2. Transfer supernatant to fresh $50-\mathrm{ml}$ tubes, and centrifuge again.

3. Wash the antibody-coated Dynabeads as recommended by the manufacturer (i.e., five times in $5 \mathrm{ml}$ of PBS containing $3 \mathrm{mg} / \mathrm{ml} \mathrm{BSA}$ ) using magnetic separation.

4. Pellet the beads using the magnet, and remove all buffer. To this pellet add the supernatant from step 2 .

The easiest method for defining conditions for bead saturation is to perform a dilution series (of cell numbers or of exosome-rich supernatant), and to capture exosomes using a fixed number of beads, in a fixed volume of medium. After washing, beads are stained (preferably with direct-conjugated antibody against a strongly expressed exosome protein e.g., MHC Class I), and the fluorescence intensity measured by flow cytometry. A plot of bead:cell ratio versus mean fluorescence intensity should be drawn, and from this graph, it should be clear at around which point a maximum (plateau) is reached-i.e., adding more exosomes to the beads results in no further increase in signal because the bead surface is already completely saturated. Examples are shown in Clayton et al. (2001).

For cells such as B cells, which produce abundant exosomes, cells are typically seeded at $1-5 \times 10^{6} \mathrm{cells} / \mathrm{ml}$ and allowed to condition the medium for 24 to $48 \mathrm{hr}$. About 10 to 
$50 \mathrm{ml}$ of precleared supernatant is added to $0.5-5 \times 10^{6}$ beads. (A half million beads is usually sufficient for the analysis of 10 to 20 different surface markers i.e., 10 to 20 FACS tubes, each representing staining with a particular antibody). For nonimmune cells, start with the same ratio as for $B$ cells and adjust as necessary.

Dynal provides the concentration of the bead stock (usually 400,000 beads/ml). The beads can also be counted using a hemacytometer.

5. Incubate $24 \mathrm{hr}$ at room temperature or at $4{ }^{\circ} \mathrm{C}$ (to limit proteolysis) on a test tube rolling machine to allow complete bead saturation.

Do not use a test tube rotating shaker because it may be very harsh and encourage formation of bubbles in protein rich supernatants. The bubbles will trap the magnetic beads and make it difficult to pull them into a pellet using a magnet.

In almost all situations, it is desirable to obtain beads that are completely saturated with exosomes (for examples of the possible use of partially coated beads see Clayton et al., 2001). Subsequent analysis of exosome-bead complexes, will therefore give the maximum possible signal. It is especially important to be sure that the saturating condition has been achieved if comparing exosome phenotypes from different cell lines, for example. Two key factors dictate the bead coupling efficiency: (1) the coupling time and (2) the ratio of beads to exosomes.

For an exosome in solution to bind to the surface of a bead it is essential that the exosome makes contact with the bead. If the coupling time is long, the likelihood that such an interaction occurs is increased; hence, long coupling times result in better bead coating.

However, coupling is entirely dependent on the concentration of exosomes in the supernatant, and beads reach saturation more quickly in exosome-rich medium. In practical terms, the authors have found that an overnight coupling gives the best bead-coating results and extending the time beyond $27 \mathrm{hr}$ has no beneficial effect on the extent of bead coating. If time is short, however, incubations of $\sim 1$ to $3 \mathrm{hr}$ give $\sim 50 \%$ to $70 \%$ bead saturation. If the exosomes are particularly dilute (i.e., cell density is low, or cells produce few exosomes) extending the coupling time will be of little benefit. Optimal bead saturation occurs if there is a vast excess of exosomes present in the supernatant relative to beads.

In practice, use only as much of the bead preparation as is required $(20,000$ to 50,000 beads per flow cytometry antibody, or $5-10 \times 10^{6}$ beads per well for immunoblotting), and condition the medium with as many cells as possible. As a guide, the authors suggest using at least 100 cells for every bead, but this ratio will vary considerably among different cell types and with duration of cell culture.

6. Collect the beads with the magnet, and wash at least three times with 2 to $10 \mathrm{ml}$ PBS containing $3 \mathrm{mg} / \mathrm{ml} \mathrm{BSA}$ to remove material that is nonspecifically bound.

7. Finally, wash once in $\sim 10 \mathrm{ml}$ PBS as in step 6 to reduce BSA content.

8. Resuspend beads in $100 \mu \mathrm{l}$ of PBS for FACS (Support Protocol 10) or continuous sucrose gradient (Support Protocol 7) analysis, SDS sample buffer for immunoblotting (Support Protocol 8), or fixative for electron microscopy (Clayton et al. 2001).

\section{ELECTRON MICROSCOPE ANALYSIS OF WHOLE-MOUNTED EXOSOMES}

Standard electron microscopic (EM) methods requiring fixation, dehydration, resin embedding, and ultrathin sectioning that are currently used for tissues, cells, and subcellular fractions are, in the authors' opinions, difficult to apply to exosomes and do not give a representative view of the preparation because membranes may be lost during dehydration and repeated centrifugation steps related to dehydration and embedding. This protocol describes a quick and reliable contrasting and embedding method that permits EM analysis of whole-mount exosome preparations.

SUPPORT PROTOCOL 4

Subcellular Fractionation and Isolation of Organelles

3.22.11

Supplement 30 


\section{Materials}

$100,000 \times g$ exosome pellet or frozen concentrated exosome preparations (Basic Protocol 1 or Support Protocol 3)

$2 \%$ or $4 \%(\mathrm{w} / \mathrm{v})$ paraformaldehyde (PFA; see recipe)

Phosphate-buffered saline (PBS; APPENDIX 2A)

$1 \%$ glutaraldehyde (see recipe)

Uranyl-oxalate, $\mathrm{pH} 7$ (see recipe)

Methyl cellulose-UA, $\mathrm{pH}$ 4: 9 parts 2\% methyl cellulose (see recipe) and 1 part 4\% uranyl acetate (see recipe) mixed just before use

Formvar-carbon coated EM grids (Support Protocol 6; also see Video 11 for UNIT 4.7 at http://www.currentprotocols.com)

Parafilm

Forceps (Dumont no. 5), clean

Glass dish

Stainless steel loops (homemade; see Video 1 for UNIT 4.7 at

http://www.currentprotocols.com), slightly larger than grids

Whatman no. 1 filter paper

Grid storage boxes (e.g., PELCO; http://tedpella.com)

Transmission electron microscope (TEM)

\section{Fix exosomes on electron-microscope grids}

1. Resuspend the $100,000 \times g$ exosome-containing pellet in 50 to $100 \mu \mathrm{l}$ of $2 \%$ PFA.

Purified concentrated exosomes frozen at $-20^{\circ} \mathrm{C}$ or $-80^{\circ} \mathrm{C}$ are thawed and mixed with an equal volume of $4 \%$ PFA.

Exosomes in $2 \%$ PFA can be stored up to 1 week at $4^{\circ} \mathrm{C}$ before proceeding further.

2. Deposit $5 \mu \mathrm{l}$ resuspended pellets on Formvar-carbon coated EM grids. Prepare two or three grids for each exosome preparation. Cover and let the membranes adsorb for $20 \mathrm{~min}$ in a dry environment.

Alternatively, put a drop of 5 to $10 \mu \mathrm{l}$ of exosome suspension on clean Parafilm. In this case float the grids on the drop with their coated side facing the suspension.

3. Put 100- $\mu$ l drops of PBS on a sheet of Parafilm. Transfer the grids (membrane side down) to drops of PBS with clean forceps to wash.

IMPORTANT NOTE: It is important to keep the grids wet on the side of membrane adsorption during all steps, but dry on the opposite side.

Subsequent procedures are performed in the same manner: placing drops of reagents on a sheet of Parafilm and transferring the grids from drop to drop with forceps.

Grids with the same sample can be handled in the same drop.

4. Transfer the grids to a $50-\mu 1$ drop of $1 \%$ glutaraldehyde for $5 \mathrm{~min}$.

5. Transfer to a 100- $\mu$ l drop of distilled water and let grids stand for $2 \mathrm{~min}$. Repeat seven times for a total of eight water washes.

\section{Contrast and embed samples}

6. Transfer grids to a 50- $\mu$ l drop of uranyl-oxalate solution, $\mathrm{pH} 7$, for $5 \mathrm{~min}$.

Samples are contrasted first in a solution of uranyl oxalate, $\mathrm{pH} 7$ and then contrasted and embedded in a mixture of $4 \%$ uranyl acetate and $2 \%$ methyl cellulose in a ratio of $100 \mu l / 900 \mu l$, respectively.

Isolation and Characterization of Exosomes

3.22.12
7. Transfer grids to a 50- $\mu$ d drop of methyl cellulose-UA for $10 \mathrm{~min}$ on ice. To keep the grids cold; use a glass dish covered with Parafilm on ice. 
A

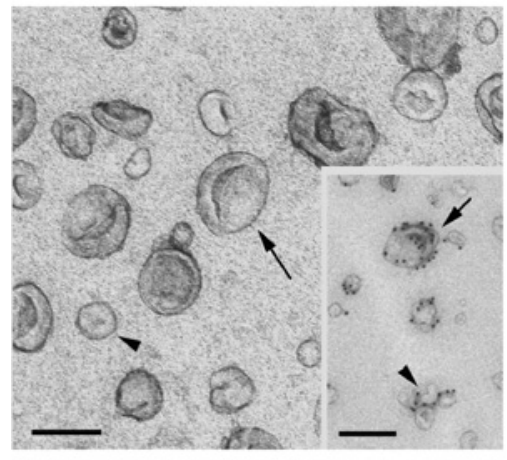

$B$

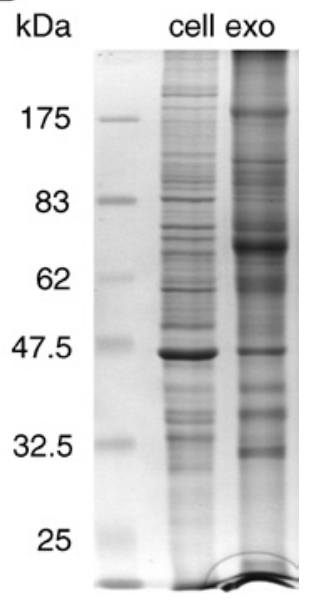

Figure 3.22.2 Typical characteristics of exosomes. (A) Electron-microscopic observation of whole-mounted exosomes purified from mouse dendritic cells. Arrows indicate exosomes, arrowheads point to smaller nonexosomal vesicles. Insert: Immunogold labeling of MHC class II molecules (10-nm gold particles). Scale bar $=100 \mathrm{~nm}$. (B) Coomassie blue-stained SDS polyacrylamide gel after separation of $30 \mu \mathrm{g}$ of total cell lysates (Cell) or exosomes (Exo) from mouse dendritic cells. Molecular weight markers were loaded in the first lane (kDa).

This contrasting and embedding procedure ("positive-negative" contrast) was originally developed for ultrathin cryosections. This method is reproducible and combines both increase in contrast and stabilization of the membranes.

8. Remove the grids with stainless steel loops and blot excess fluid by gently pushing the loop sideways on Whatman no. 1 filter paper so that a thin film is left behind over the exosome side of the grid. (See Video 3 of UNIT 4.7 at http://www.currentprotocols.com.)

It is essential to control the thickness of the methyl-cellulose film. The final thickness of the film is critical in obtaining optimal contrast and fine structure preservation. This can be controlled by the speed of adsorption onto the filter paper (the faster this goes the thicker the film). In the authors' laboratory a sheet of Whatman no. 1 filter paper is placed on top of Parafilm to avoid contamination of the bench with uranyl acetate.

Loops are slightly larger than the grids and are generally mounted on 1-ml plastic micropipettor tips.

9. Air dry the grid 5 to 10 min while still on the loop.

After drying, a blue-gold interference color is indicative of a homogeneous and appropriate thickness of the methyl-cellulose film.

10. Store the grids in appropriate grid storage boxes for many years.

11. Observe under the electron microscope at $80 \mathrm{kV}$.

Electron microscopy of negatively stained exosomes reveals cup-shaped membrane vesicles of 50 to $90 \mathrm{~nm}$ (Fig. 3.22.2). Often, smaller 10- to 20-nm lipid particles are also observed within the same preparations. It is possible that the morphological appearance of exosomes may be influenced by chemical fixation and/or embedding and contrasting with methyl cellulose and uranyl acetate. Unpublished observations of cryo-fixed no-contrasted exosomes visualized with cryo-electron microscopy reveal rather round membrane vesicles.

Analysis of the 100,000 $\times \mathrm{g}$ pellets at the electron microscopic level is also essential in evaluating contamination of exosome preparations by other membranes that may be present in culture supernatants as a consequence of cell lysis and may be pelleted during centrifugation.

Subcellular Fractionation and Isolation of Organelles

3.22.13 
SUPPORT PROTOCOL 5
Isolation and Characterization of Exosomes

\subsubsection{4}

\section{IMMUNOGOLD LABELING OF WHOLE-MOUNT EXOSOMES}

For further characterization of exosomes, immunolabeling with antibodies against proteins known to be exposed on exosomal membranes is recommended before electron microscopy. A standard immunolabeling procedure is difficult to establish because each antibody/antigen combination may require a slightly different approach.

The most commonly used single antigen-specific labeling procedures are specific antibody + Protein A-gold (PAG) or specific antibody + bridging antibody + PAG. IgG conjugated to gold probes can also be used. The specific antibody can be either a monoclonal or a polyclonal antibody, the bridging antibody or IgG conjugated to the gold probe must originate from a different species. A bridging antibody can be used either to amplify the signal or in situations where the specific antibody does not react with PAG or the IgG-gold. The labeling efficiency, specificity, and background of bridging antibodies depend on the source and should be tested when handling antibodies from different manufacturers.

Multiple antigen-specific immunolabeling procedures can be accomplished using two or more consecutive single-labeling procedures. Up to three different antigens can be visualized (double- and triple-immunolabeling). When performing double or triple immunolabeling, one should consider the best choice of the size of gold particles to be used in the first, second, or third step and for the sequence of gold probes and antibodies. This should be tested first in a single-labeling procedure. Also take into account that, given the small size of exosomes, steric hindrance may hide epitopes and give a negative result.

The procedure described in this protocol was used by Escola et al. (1998), Raposo et al. (1996), Théry et al. (1999), Van Niel et al. (2001), and Zitvogel et al. (1998), to localize proteins exposed at the surface of exosomes. To visualize proteins on the cytosolic side of exosomes (e.g., Tsg101) one may introduce a permeabilization step with saponin after the fixation procedure and during incubation with antibodies and PAG (Fevrier et al., 2004). However, permeabilization of exosomal membranes is difficult to control and may affect exosome morphology.

\section{Materials}

$100,000 \times g$ exosome pellet (Basic Protocol 1)

$2 \%$ or $4 \%(\mathrm{w} / \mathrm{v})$ paraformaldehyde (PFA; see recipe)

Phosphate-buffered saline (PBS; APPENDIX 2A)

$\mathrm{PBS} / 50 \mathrm{mM}$ glycine or $\mathrm{PBS} / 50 \mathrm{mM} \mathrm{NH}_{4} \mathrm{Cl}$

Blocking buffer: PBS/5\% (w/v) BSA, PBS/10\% (v/v) fetal calf serum (FCS), or $\mathrm{PBS} / 1 \%(\mathrm{w} / \mathrm{v})$ cold-water fish skin gelatin (CFG; Sigma Aldrich)

Primary antibody

Antibody diluent: PBS/1\% (w/v) BSA, PBS/5\% (v/v) FCS, or PBS/1\% (w/v) cold-water fish skin gelatin

Washing buffer: PBS/0.1\% (w/v) BSA, PBS/0.1\% (v/v) FCS, or PBS/0.1\% (w/v) CFG

Secondary (bridging) antibody (optional; e.g., Dakopatt)

PBS/0.5\% (w/v) BSA

Protein A-gold conjugates (Cell Microscopy Center, Utrecht, The Netherlands)

$1 \%$ glutaraldehyde (see recipe)

Formvar-carbon coated EM grids (Support Protocol 6 or Pelco International, http://www.pelcoint.com)

Parafilm

Clean forceps (Dumont no. 5)

Additional reagents and equipment for contrasting, embedding, and electron microscopy (Support Protocol 4) 
Adsorb exosomes on electron-microscope grids

1. Resuspend the $100,000 \times g$ exosome-containing pellet in 50 to $100 \mu \mathrm{l}$ of $2 \%$ PFA.

Purified concentrated exosomes frozen at $-20^{\circ} \mathrm{C}$ or $-80^{\circ} \mathrm{C}$ are thawed and mixed with an equal volume of $4 \% P F A$.

Exosomes in 2\% PFA can be stored up to 1 week at $4^{\circ} \mathrm{C}$ before proceeding further.

2. Deposit $5 \mu \mathrm{l}$ of the resuspended pellets on Formvar-carbon coated electronmicroscopy grids. Prepare two or three grids for each exosome preparation. Cover and let the membranes adsorb for $20 \mathrm{~min}$ in a dry environment.

Alternatively, put a drop of 5 to $10 \mu \mathrm{l}$ of exosome suspension on clean Parafilm. In this case float the grids on the drop with their coated side facing the suspension.

3. Put 100- $\mu$ l drops of PBS on a sheet of Parafilm. Transfer the grids to drops of PBS with clean forceps.

IMPORTANT NOTE: It is important to keep the grids wet on the side of membrane adsorption during all steps, but dry on the opposite side.

Grids with the same sample can be handled in the same drop.

The immunolabeling procedure is performed by floating the exosome-coated electronmicroscope grids on successive drops of washing, blocking, and labeling solutions disposed on a Parafilm sheet. Each rinsing step is performed on drops of at least $100 \mu \mathrm{l}$, while 5- $\mu \mathrm{l}$ drops are sufficient for immunoreagents.

The following steps proceed by floating grids on 100- to 200- $\mu$ l droplets of solutions.

\section{Wash and block exosomes on grids}

4. Transfer grid to PBS and wash twice for $3 \mathrm{~min}$.

5. Transfer grid to PBS/50 $\mathrm{mM}$ glycine for $3 \mathrm{~min}$. Repeat transfers to fresh drops of $\mathrm{PBS} / 50 \mathrm{mM}$ glycine three times for a total of four washes.

The glycine quenches free aldehyde groups. As an alternative use a $50 \mathrm{mM}$ solution of ammonium chloride $\left(\mathrm{NH}_{4} \mathrm{Cl}\right)$.

6. Transfer grids to a drop of blocking buffer for $10 \mathrm{~min}$

Bovine serum albumin (BSA) and other proteins saturate nonspecific binding sites. Alternative blocking solutions are 10\% fetal calf serum (FCS) or 1\% cold-water fish skin gelatin $(C F G)$ in $P B S$.

Diluents and washing buffers in following steps should contain the same proteins as the blocking buffer.

\section{Incubate exosomes with antibodies}

7. Transfer the grid to a 5- $\mu$ l drop with the first antibody diluted in the appropriate antibody diluent for the blocking solution and incubate $30 \mathrm{~min}$.

Test a range of antibody dilutions from 2 to $20 \mu \mathrm{g} / \mathrm{ml}$.

As in any labeling procedure it is critical to avoid contamination of solutions. Buffers should be freshly prepared, and antibody dilutions can be kept from 1 week to 1 month, depending on the antibody.

8. Transfer grids to the appropriate washing buffer and wash 3 min. Repeat transfers to fresh drops of washing buffer five times for a total of six washes.

It is important to keep the grids wet on the specimen side during all steps, but dry at the opposite side. When the samples are allowed to dry during the immunoincubation, high background levels or other contamination can result.

Subcellular Fractionation and Isolation of Organelles

3.22.15 
If the first antibody is not directly reactive with protein A (for example mouse monoclonal IgG1, rat monoclonals, goat polyclonals), use a bridging antibody: for example, rabbit anti-mouse IgM, rabbit anti-goat IgG, rabbit anti-rat (commercially available from Dakopatt).

9. (Optional): If it is necessary to perform bridging, incubate 30 min with a secondary antibody diluted in the appropriate blocking solution.

10. Transfer grids to $100-\mu l$ drops of PBS/0.5\% BSA (blocking buffer) and wash 3 min. Repeat transfers to fresh drops of PBS/0.5\% BSA five times for a total of six washes.

\section{Label exosomes with protein A-gold conjugates}

11. Incubate in 5- $\mu$ l drops of protein A-gold conjugates diluted in the appropriate blocking buffer $20 \mathrm{~min}$.

For a single labeling the authors generally use 10-nm gold particles.

Protein A-gold of excellent quality with appropriate dilutions indicated by the supplier can be purchased from Cell Microscopy Center, Department of Cell Biology, Utrecht University, The Netherlands. These reagents are extremely pure, the dilutions have been perfectly controlled, and the same batches (made four times a year) are used by different labs.

The authors recommend a 1:200 dilution when using Dako bridging antibodies.

12. Transfer grids to $100-\mu l$ drops of PBS and wash 2 min. Repeat transfers to fresh drops of PBS seven times for a total of eight washes.

13. Transfer grids to $50-\mu 1$ drops of $1 \%$ glutaraldehyde for $5 \mathrm{~min}$.

This step is necessary to stabilize the immunoreaction.

14. Transfer grids to $100-\mu l$ drops of water and wash 2 min. Repeat transfers to fresh drops of water seven times for a total of eight washes.

This step is necessary to remove ions responsible for precipitates during contrast enhancement.

When performing a double labeling, proceed with steps 3 to 14 with the second label.

\section{Prepare labeled exosomes for electron microscopy}

15. Contrast and embed the grids as in Support Protocol 4, steps 6 to 10.

16. Observe under the electron microscope at $80 \mathrm{kV}$. See Figure 3.22.2.

SUPPORT PROTOCOL 6

Isolation and Characterization of Exosomes

3.22.16

\section{PREPARATION OF FORMVAR-CARBON COATED GRIDS}

The successful adsorption of exosomal membranes onto grids depends on the quality of the support film. Commercially available Formvar-carbon coated grids can be purchased from Leica or Pelco International (http://www.pelcoint.com). This protocol describes a method that is currently used in several laboratories to prepare clean and strong Formvar films. (Also see Video 11 for UNIT 4.7 at http://www.currentprotocols.com.)

\section{Materials}

Ethanol

Acetone

Formvar powder (Agar Scientific, http://www.agarscientific.com)

Chloroform

EM grids, 200 mesh/copper-palladium, hexagonal specimen (e.g., PELCO; http://tedpella.com)

Warming plate or $37^{\circ} \mathrm{C}$ drying oven 
100-ml volumetric flask: rinse with chloroform before use

Funnel-shaped glass column with a stopcock (e.g., PELCO; http://tedpella.com;

Electron Microscopy Sciences): rinse with chloroform before use

Glass microscope slides

Lens tissue

Deep glass dish: rinse with chloroform before use

Clean forceps

Razor blades

Adhesive label (e.g., address label) or Parafilm

Petri dishes with tops

Filter paper

Carbon vacuum evaporator (Bal-tec, http://www.bal-tec.com)

\section{Create Formvar film on microscope slide}

1. Clean EM grids in a $200 \mathrm{ml}$ glass flask, by rinsing them $\sim 5$ min with ethanol and then three times, $\sim 3$ min each, in acetone. Remove acetone.

2. Dry over a $37^{\circ} \mathrm{C}$ warming plate or in a drying oven.

3. Put $1.2 \mathrm{~g}$ Formvar powder into a $100-\mathrm{ml}$ volumetric flask and add $100 \mathrm{ml}$ chloroform with stirring. Let stand overnight wrapped in aluminum foil to protect from light.

In order to prepare a clean solution all materials should be previously rinsed with chloroform.

4. Clean a glass slide with ethanol and dry it immediately with lens tissue.

5. Fill the glass column with Formvar solution. Using clean forceps, introduce the clean slide upright in the solution.

The glass column is funnel-shaped and specially designed to accommodate the slide. The column should be previously rinsed with chloroform.

6. Open the stopcock to allow the Formvar to drain over the slide.

This leaves a thin film of Formvar on the slide. The draining time determines the thickness of the film, and is usually 12 to $15 \mathrm{sec}$.

7. Remove the slide from the funnel and let the slide dry vertically.

\section{Transfer Formvar film to EM grid}

8. Fill a deep glass dish with water and place a light so that it reflects on the water surface. Clean the water surface by passing a piece of lens tissue over the surface.

9. Cut the edges of the dry Formvar film around the slide with a razor blade.

10. Put the slide on a water surface in an upright position. Push the slide gently into the water to allow the film to be released from the slide and to float on the water surface.

The thickness of the film can be judged by its color, which ideally should be grey/white. If the films are yellow-purple, they are too thick. Either dilute the solution with chloroform or decrease the speed of draining with the stopcock.

11. Place the grids on the film floating on the water surface.

12. Remove the grids/film from the water by putting a microscope slide covered with an adhesive label in an upright position on the edge of the film, and pushing it downwards into the water.

The film with the grids will stick to the label. Clean Parafilm can be used instead of the label.

Subcellular

Fractionation and Isolation of Organelles

3.22.17 
SUPPORT PROTOCOL 7
13. Place the slides filled with grids in plastic dishes over a filter paper and let dry overnight at room temperature.

14. Evaporate a thin layer of carbon on the grids using a carbon-vacuum evaporator according to the manufacturer's instructions. Store in a covered petri dish.

\section{DETERMINATION OF THE DENSITY OF AN EXOSOME PREPARATION ON A CONTINUOUS SUCROSE GRADIENT}

This method measures the density of exosomes in a sucrose gradient. Exosomes have been found to float at densities ranging from 1.15 to $1.19 \mathrm{~g} / \mathrm{ml}$ on continuous sucrose gradients. By comparison, vesicles purified from the endoplasmic reticulum float at 1.18 to $1.25 \mathrm{~g} / \mathrm{ml}$, and vesicles from the Golgi at 1.05 to $1.12 \mathrm{~g} / \mathrm{ml}$.

Since exosomes are usually spread among three to five fractions of the sucrose gradient, it is best to perform this separation on at least five times the amount of exosomal proteins needed to detect exosomes after this procedure. For example, to perform an immunoblot on the sucrose-gradient fractions using an antibody that detects its target among $3 \mu \mathrm{g}$ of exosomal proteins, perform the sucrose gradient on 15 to $20 \mu \mathrm{g}$ of exosomal proteins. To visualize exosomal proteins in the sucrose-gradient fractions by Coomassie blue staining on gels, use $100 \mu \mathrm{g}$ of exosomal proteins, to obtain about $20 \mu \mathrm{g}$ in each exosomal sucrose gradient fraction.

\section{Materials}

Exosome preparation (Basic Protocol 1, step 12 or Basic Protocol 2, step 8)

HEPES/sucrose stock solution (see recipe)

HEPES stock solution (see recipe)

$4 \times$ SDS sample buffer (APPENDIX 2A)

30-ml gradient maker

Ultracentrifuge with SW 41 rotor

3-ml ultraclear tubes

Tabletop ultracentrifuge with TLA-100.3 rotor

3-ml thick-walled polycarbonate ultracentrifuge tubes

Refractometer

Additional reagents and equipment for SDS-PAGE (UNIT 6.1), protein staining (UNIT 6.6), and immunoblotting (UNIT 6.2)

\section{Prepare and pour exosome-containing sucrose gradient}

1. For each gradient (i.e., each exosome preparation to be analyzed) prepare $5 \mathrm{ml}$ of $2 \mathrm{M}$ sucrose solution by mixing $4 \mathrm{ml} \mathrm{HEPES/sucrose} \mathrm{stock} \mathrm{solution} \mathrm{and} 1 \mathrm{ml}$ HEPES stock solution.

2. For each gradient, prepare $5 \mathrm{ml}$ of $0.25 \mathrm{M}$ sucrose solution by mixing $0.5 \mathrm{ml}$ HEPES/sucrose stock solution and $4.5 \mathrm{ml}$ HEPES stock solution.

3. Resuspend exosomes in $2 \mathrm{ml}$ of HEPES/sucrose stock solution.

4. Pour exosomes at the bottom of an SW 41 centrifuge tube.

5. In the gradient maker with all shutters closed, load $5 \mathrm{ml}$ of $2 \mathrm{M}$ sucrose solution in the proximal compartment with a magnetic stir bar, and $5 \mathrm{ml}$ of $0.25 \mathrm{M}$ sucrose solution in the distal compartment.

6. Put the gradient maker on a high shelf, on a magnetic stir plate. Open shutter between proximal and distal compartments and turn on the magnetic stir plate. 
7. Place the outer tubing in the SW 41 tube, just above the $2 \mathrm{ml}$ of exosomes.

8. Open the outer shutter, and slowly pour a continuous $2 \mathrm{M}$ (bottom) to $0.25 \mathrm{M}$ (top) sucrose gradient on top of the exosomes.

Lower the SW 41 tube as the gradient is poured, so that the tubing is always slightly above the top of the liquid.

It is often worth pouring a test gradient on top of non-exosome-containing sucrose first, to get used to the procedure.

9. Balance all tubes containing gradient with each other, or with other tubes containing the same weight of sucrose solutions.

\section{Centrifuge gradients and collect fractions}

10. Centrifuge the gradients overnight $\left(\geq 14 \mathrm{hr}\right.$ ) at $210,000 \times g, 4^{\circ} \mathrm{C}$, in the $\mathrm{SW} 41$ swinging-bucket rotor with the brake set on low.

Total centrifugation time must be at least $14 \mathrm{hr}$. Set the centrifuge on hold in the evening, and turn it off on arrival in the morning

11. With a micropipettor, collect eleven 1-ml fractions, from top to bottom. Put each fraction in a $3-\mathrm{ml}$ tube for the TLA-100.3 rotor

\section{Measure refractive index}

12. Set aside, in separate wells of a 96 -well plate, $50 \mu \mathrm{l}$ of each fraction to use to measure the refractive index. Cover the plate with adhesive foil to prevent evaporation. Store up to $1 \mathrm{hr}$ at room temperature.

13. Use a refractometer to measure the refractive index (hence the sucrose concentration, and the density) of 10 to $20 \mu \mathrm{l}$ of each fraction from the material saved in the 96-well plate.

A table for converting the refractive index into $\mathrm{g} / \mathrm{ml}$ is available in the ultracentrifugation catalog downloadable from the Beckman website.

\section{Prepare fractions for analysis by SDS-PAGE}

14. Add $2 \mathrm{ml}$ of $20 \mathrm{mM}$ HEPES, $\mathrm{pH} 7.4$, to each 1-ml gradient fraction, and mix by pipetting up and down two to three times.

15. Mark one side of each tube with a permanent marker, and place the tubes marked side up in a TLA-100.3 rotor.

16. Centrifuge the $3 \mathrm{ml}$-tubes containing diluted fractions $1 \mathrm{hr}$ at $110,000 \times g, 4^{\circ} \mathrm{C}$.

The TLA-100.3 rotor holds six tubes, so it is necessary to perform two centrifugations for each gradient. Keep the other tubes at $4^{\circ} \mathrm{C}$ until they can be centrifuged.

17. Aspirate the supernatant from each of the 3-ml tubes, leaving a drop on top of the pellet.

The pellet most probably is not visible, but its location can be inferred from the mark on the tube. See Basic Protocol 1.

18. Resuspend the invisible pellet and transfer to microcentrifuge tube.

19. Store half of each resuspended fraction up to 1 year at $-80^{\circ} \mathrm{C}$. To the other half of each resuspended fraction add one third of that volume of $4 \times$ SDS sample buffer.

This will result in a $1 \times$ final concentration of SDS sample buffer.

The stored fractions can be used for other purposes (e.g. functional analysis, or further purification by immunoisolation, step 22) once gel analysis (step 21) has revealed which fractions contain exosomes.

Subcellular Fractionation and Isolation of Organelles

3.22.19 
20. Heat samples in SDS sample buffer from step 19 a to $70^{\circ} \mathrm{C}$ for $10 \mathrm{~min}$ or $95^{\circ} \mathrm{C}$ for $5 \mathrm{~min}$, and load half onto a $10 \%$ or $12 \%$ SDS-PAGE gel for further analysis (UNIT 6.1).

21. Analyze the gel by immunoblotting (UNIT 6.2) to visualize different exosome markers (Table 3.22.2), or Coomassie blue staining (UNIT 6.6) to visualize all proteins.

Most proteins should be recovered in fractions with densities of 1.15 to $1.20 \mathrm{~g} / \mathrm{ml}$. Contaminants that are not specifically associated with exosomes will be recovered in the densest fractions collected from the bottom of the tube $(>1.25 \mathrm{~g} / \mathrm{ml})$

\section{Purify fractions by immunoisolation}

22. Thaw frozen fractions from step 19 on ice, and pool exosome-containing gradient fractions (as determined in step 21). Dilute to $1.5 \mathrm{ml}$ final with PBS.

23. In one microcentrifuge tube, combine $750 \mu \mathrm{l}$ of the pooled fractions with $200 \mu \mathrm{l}$ of antibody-coated Dynabeads $\left(8 \times 10^{7}\right.$ beads). In another microcentrifuge tube, combine $750 \mu \mathrm{l}$ with $200 \mu \mathrm{l}$ of goat anti mouse IgG-coated Dynabeads as a negative control.

24. Proceed further as in Basic Protocol 3.

See Wubbolts et al., 2003 for more details.

SUPPORT PROTOCOL 8
Isolation and Characterization of Exosomes

\subsubsection{0}

\section{IMMUNOBLOT ANALYSIS OF EXOSOMES}

The overall protein composition of exosomes from various cellular sources has been investigated by several groups, using extensive proteomic analysis, immunoblotting (western blots), or FACS. Exosome sources include various immortalized cell lines or tumor cells (Clayton et al., 2001; Skokos et al., 2001; Blanchard et al., 2002; Van Niel et al., 2003; Wubboltz et al., 2003; Amzallag et al., 2004; Fevrier et al., 2004; Hegmans et al., 2004; Mears et al., 2004; Segura et al., 2005), primary cells (Heijnen et al., 1999; de Gassart et al., 2003), or bodily fluids (Bard et al., 2004; Pisitkun et al., 2004; Caby et al., 2005). Several proteins were consistently found in exosomes from many of these different sources.

To characterize the purified vesicles as exosomes, it is important to show that most of the common exosomal proteins are present. Immunoblotting is a convenient way to accomplish this. Table 3.22.2 gives an overview of the exosomal proteins that can be identified by immunoblotting. To show that a given protein is specifically enriched in exosomes, it is important to compare on the same gel identical amounts of protein from exosomes and from total lysates prepared from the producing cells. To give a more accurate quantification and to allow detection of proteins which are not very abundant in either exosomes or cells, two different amounts of exosomal or total cell proteins are run side by side on the SDS-gel for subsequent immunoblot analysis.

\section{Materials}

Exosomes (pellet from Basic Protocol 1, step 10; Basic Protocol 2, step 8; or Basic Protocol 3, step 8)

Whole cell lysates: prepared from same cell source as exosomes (Support Protocol 1 , step 8)

Phosphate-buffered saline (PBS; APPENDIX 2A)

$4 \times$ SDS sample buffer, reducing or nonreducing (i.e., with or without DTT or 2-mercaptoethanol; APPENDIX 2A)

Additional reagents and equipment for quantifying protein (Support Protocol 9), SDS-PAGE (UNIT 6.1); and western blots (immunoblotting; UNIT 6.2) 
Table 3.22.2 Characteristic Protein Markers of Exosomes, as Assessed by Immunoblot

\begin{tabular}{|c|c|c|c|c|}
\hline Protein & $\begin{array}{l}\mathrm{MW} \\
(\mathrm{kDa})\end{array}$ & $\begin{array}{l}\text { Cells types with } \\
\text { exosomes containing } \\
\text { the protein }{ }^{a}\end{array}$ & $\begin{array}{l}\text { Enrichment in } \\
\text { exosomes }\end{array}$ & Remarks \\
\hline Alix & 96 & $\mathrm{DC}, \mathrm{M}, \mathrm{U}$ & Medium & MVB marker \\
\hline Annexin II & 38 & $\begin{array}{l}\text { DC, M, IEC, MC, } \\
\text { Mov, U }\end{array}$ & Low & \\
\hline B7-2 & 80 & DC, B, Mast & High & $\begin{array}{l}\text { Not all cells express } \\
\text { B7-2 }\end{array}$ \\
\hline Calnexin & 96 & & $\begin{array}{l}\text { Absent in } \\
\text { exosomes }\end{array}$ & $\begin{array}{l}\text { Endoplasmic } \\
\text { reticulum marker }\end{array}$ \\
\hline CD9 & 25 & DC, IEC, U, P & High & $\begin{array}{l}\text { Do not use } \\
\text { 2-mercaptoethanol } \\
\text { or DTT in samples }\end{array}$ \\
\hline CD63, CD81 & $50-60$ & Human: DC, B, IEC & High & $\begin{array}{l}\text { Do not use } \\
\text { 2-mercaptoethanol } \\
\text { or DTT in samples }\end{array}$ \\
\hline Clathrin & 192 & DC, IEC, B, HEK & Medium & \\
\hline Flotillin-1 & 48 & DC, Mov, U, Ret & Medium & $\begin{array}{l}\text { Associated with } \\
\text { lipid rafts }\end{array}$ \\
\hline $\mathrm{Gi} 2 \alpha$ & 40 & DC, Mov, U, B, Ret & Medium & \\
\hline Grp94 (or gp96) & 96 & & $\begin{array}{l}\text { Absent in } \\
\text { exosomes }\end{array}$ & $\begin{array}{l}\text { Endoplasmic } \\
\text { reticulum marker }\end{array}$ \\
\hline Hsc70 & 70 & $\begin{array}{l}\text { DC, M, MC, Mov, U, } \\
\text { B, Ret, Mast }\end{array}$ & Low & \\
\hline ICAM-1 & 90 & Mature DC, B & $\begin{array}{l}\text { Variable, } \\
\text { depending on the } \\
\text { cell type }\end{array}$ & $\begin{array}{l}\text { Do not use } \\
\text { 2-mercaptoethanol } \\
\text { or DTT in samples }\end{array}$ \\
\hline Lamp-1 or 2 & 90 & DC, B & Low & $\begin{array}{l}\text { Enrichment of } \\
\text { lamp-1 or lamp- } 2 \text { on } \\
\text { exosomes depends } \\
\text { on the cell type }\end{array}$ \\
\hline MFG-E8 & $\begin{array}{l}70+ \\
60\end{array}$ & DC, IEC, Mov & $\begin{array}{l}\text { Very high (not } \\
\text { detectable in cell } \\
\text { lysates) }\end{array}$ & $\begin{array}{l}\text { Not all cells express } \\
\text { MFG-E8 }\end{array}$ \\
\hline MHC I & 47 & $\begin{array}{l}\text { DC, IEC, MC, U, B, } \\
\text { T, HEK }\end{array}$ & Medium & \\
\hline MHC II & $\begin{array}{l}30(\alpha \\
\text { chain })\end{array}$ & DC, IEC, B, T, Mast & High & $\begin{array}{l}\text { Not all cells express } \\
\text { MHC II }\end{array}$ \\
\hline $\begin{array}{l}\text { Transferrin } \\
\text { receptor }\end{array}$ & 90 & DC, Mov, Ret & $\begin{array}{l}\text { Variable, } \\
\text { depending on the } \\
\text { cell type }\end{array}$ & \\
\hline Tsg101 & 44 & DC, Mov, U & Medium & MVB marker \\
\hline
\end{tabular}

${ }^{a}$ Abbreviations for cell types: B, B cells; DC, dendritic cells; HEK, human embryonic kidney cells; IEC, intestinal epithelial cells; Mast, mast cells; M, melanoma cells; MC, mesothelioma cells; Mov, immortalized Schwann cells; MVB, multivesicular bodies; P, platelets; Ret, reticulocytes; T, T cells; U, urine.

Subcellular

Fractionation and Isolation of Organelles

3.22.21 
SUPPORT PROTOCOL 9
Isolation and Characterization of Exosomes

\subsubsection{2}

1. Quantify the protein content of all the samples (exosomes and cell lysates) in the same assay (Support Protocol 9).

2. For each sample, prepare a tube with $10 \mu \mathrm{g}$ and a tube with $3 \mu \mathrm{g}$ of cell lysate, a tube of $3 \mu \mathrm{g}$ and a tube of $10 \mu \mathrm{g}$ (if possible) of exosomes.

3. Add PBS to a final volume of $20 \mu \mathrm{l}$ in each tube.

4. Add $6 \mu$ of $4 \times$ SDS sample buffer to each tube.

5. Heat to $70^{\circ} \mathrm{C}$ for $10 \mathrm{~min}$ or $95^{\circ} \mathrm{C}$ for $5 \mathrm{~min}$.

6. Load samples on a $10 \%$ or $12 \%$ gel, putting the two exosome samples and the two lysate samples next to each other.

See UNIT 6.1 for more information about SDS-PAGE.

7. Run the gel, transfer to a nylon membrane, and analyze by immunoblots (UNIT 6.2) with antibodies specific for exosomes markers, as listed in Table 3.22.2.

\section{MEASURING THE PROTEIN CONTENT OF EXOSOMES USING THE BRADFORD ASSAY}

Measuring the amount of total proteins present in the exosome preparations gives a rough idea of the amount of exosomes secreted by the cells. When performing immunoblots with exosomes and total cell lysates, or when comparing different exosome preparations on the same immunoblot, it is important to perform the protein quantification by the Bradford assay on all the samples at the same time. The protocol given below is a classical version of the assay adapted to a large number $(\leq 80)$ of precious samples (it uses only $10 \mu \mathrm{l}$ of each sample). It allows accurate quantification of many samples at once, by running them side by side with a standard BSA dilution curve. (Also see APPENDIX 3 H.)

\section{Materials}

BSA standards (see recipe)

Phosphate-buffered saline (PBS; APPENDIX 2A)

Cell lysates (Support Protocol 1, step 8)

Exosome preparations (Basic Protocol 1, step 12 or Basic Protocol 2, step 8)

Bradford concentrate solution (Bio-Rad)

0.5 -ml microcentrifuge tubes

Flat-bottom 96-well plates

Microplate reader with $590 \mathrm{~nm}$ filter

1. Thaw a set of BSA standards, and store up to 2 weeks at $4^{\circ} \mathrm{C}$.

2a. For Bradford assay of total cell lysates: Thaw the cell lysate in ice and dilute $10 \mu \mathrm{l}$ in $90 \mu \mathrm{l}$ PBS (i.e., 1/10).

This step will reduce the detergent used to lyse cells to a level that will not interfere with the color reaction of the Bradford assay.

2b. For Bradford assay of exosome preparations: Thaw exosomes on ice.

3. In a flat-bottom 96-well plate, load $10 \mu \mathrm{l}$ of PBS in the first well (blank) and $10 \mu \mathrm{l}$ of each standard BSA dilution in the eight following wells.

Perform all protein determinations for standards and samples in duplicate.

4. Load $8 \mu \mathrm{l}$ of PBS to each well for cell lysate samples, and $6 \mu \mathrm{l}$ of PBS to each well for exosome samples. 
5. Add $2 \mu \mathrm{l}$ of cell lysates to the wells containing $8 \mu \mathrm{l}$ PBS.

6. Homogenize each exosome sample by pipetting up and down several times, then load $5 \mu \mathrm{l}$ in the wells containing $5 \mu \mathrm{l}$ PBS.

7. Dilute Bradford concentrate solution $1 / 5$ in distilled water. Prepare enough for $200 \mu \mathrm{l}$ per well.

8. Add $200 \mu \mathrm{l}$ of diluted Bradford solution to each blank, standard, and sample well.

The color changes immediately. If the color of some samples is obviously out of line with the BSA standard curve, prepare new wells immediately with more or less sample, PBS to $10 \mu \mathrm{l}$, and $200 \mu \mathrm{l}$ of diluted Bradford solution.

9. Read OD at $590 \mathrm{~nm}$ within $10 \mathrm{~min}$.

10. Estimate the amount of exosomes purified per cell number based on the standard curve.

The authors usually obtain $0.5 \mu \mathrm{g}$ exosomes $/ 10^{6}$ immature dendritic cells in $24 \mathrm{hr}$. The amounts are quite variable with other cell lines.

\section{ANALYSIS OF EXOSOMES BY FACS OF LABELED EXOSOMES BOUND TO BEADS}

Exosomes are too small to be reliably analyzed by direct cell sorting. To overcome this problem, exosomes are fixed to beads of a size that is in the detection range of a flow cytometer. The exosomes are then labeled with fluorophore-conjugated antibodies and analyzed by FACS.

\section{Materials}

Purified exosomes (Basic Protocol 1, step 12; or Basic Protocol 2, step 8; or Basic Protocol 3)

3.9- $\mu \mathrm{m}$ latex beads, surfactant-free aldehyde/sulfate, $4 \%$ solids (Interfacial

Dynamics 12-4000; http://www.idclatex.com)

Phosphate-buffered saline (PBS; APPENDIX 2A)

PBS/1 M glycine

PBS/0.5\% (w/v) BSA

Fluorochrome-conjugated primary or secondary antibodies

Test tube rotator wheel for 1.5-ml microcentrifuge tubes

Microcentrifuge

Flow cytometer (e.g., FACScan; BD)

1a. To analyze exosomes purified by antibody-coated bead: Proceed directly to step 8 .

1b. To analyze exosomes purified by ultracentrifugation: Incubate $5 \mu \mathrm{g}$ purified exosomes as measured by Bradford assay (Support Protocol 9) with $10 \mu l$ latex beads $15 \mathrm{~min}$ at room temperature, in a $1.5-\mathrm{ml}$ microcentrifuge tube.

A nonspecific adsorption of all exosomal proteins to the latex beads occurs in this step.

2. Add PBS to a final volume of $1 \mathrm{ml}$, and incubate on a test tube rotator wheel $2 \mathrm{hr}$ at room temperature.

Overnight incubation at $4^{\circ} \mathrm{C}$ is also possible.

3. Add $110 \mu \mathrm{l}$ of $1 \mathrm{M}$ glycine (i.e., $100 \mathrm{mM}$ final), mix gently and let stand on the bench at room temperature for $30 \mathrm{~min}$.

The purpose of this step is to saturate any remaining free binding sites on beads.

SUPPORT

PROTOCOL 10

Subcellular

Fractionation and Isolation of Organelles

3.22.23 
4. Microcentrifuge $3 \mathrm{~min}$ at $4000 \mathrm{rpm}$, room temperature. Remove the supernatant and discard.

5. Resuspend the bead pellet in $1 \mathrm{ml} \mathrm{PBS} / 0.5 \% \mathrm{BSA}$ and microcentrifuge $3 \mathrm{~min}$ at $4000 \mathrm{rpm}$, room temperature. Remove the supernatant and discard.

If not enough proteins are used to coat beads, the bead pellet may be spread along the side of the tube. In this case, resuspend the beads by flushing the side of the tube with PBS $/ 0.5 \%(w / v) B S A$; the pellet will become visible after the next centrifugation

6. Resuspend the bead pellet and microcentrifuge as in step 5 to wash two more times.

7. Resuspend beads in $0.5 \mathrm{ml} \mathrm{PBS} / 0.5 \%$ BSA.

8. Incubate $10 \mu \mathrm{l}$ coated beads with $50 \mu \mathrm{l}$ anti-exosomal protein antibody diluted in PBS $/ 0.5 \%$ BSA $30 \mathrm{~min}$ at $4^{\circ} \mathrm{C}$. Wash twice with $150 \mu \mathrm{l} \mathrm{PBS} / 0.5 \%$ BSA. If necessary, incubate with $50 \mu \mathrm{l}$ secondary antibody diluted in PBS/0.5\% BSA 30 min at $4{ }^{\circ} \mathrm{C}$. Wash twice in PBS/BSA, resuspend in $200 \mu \mathrm{l}$ of PBS/BSA.

Use fluorophore-coupled primary antibodies, or noncoupled primary antibodies followed by fluorophore-coupled secondary antibodies. Always perform negative-control staining on another $10 \mu \mathrm{l}$ of beads, using an irrelevant isotype-matched primary antibody.

When analyzing exosomes purified with antibody-coated beads (Basic Protocol 3), use directly conjugated fluorescent antibodies for FACS, rather than antibodies requiring a secondary antibody step.

If the fluorescence signal is weak with antibodies specific for abundant exosomal proteins (e.g., MHC II on dendritic cell exosomes), try to increase the amount of exosomes and/or decrease the amount of beads in step 1.

9. Analyze antibody-stained exosome-coated beads on a flow cytometer. Adjust the forward scatter (FSC) and side scatter (SSC) to see both single beads and bead doublets. Gate on both single and doublet beads to analyze fluorescence. Compare fluorescence obtained with specific antibody and with irrelevant isotype control.

When performing flow cytometric analysis of exosome-coated Dynal beads it is important to be aware that these paramagnetic beads may cause blockages in certain flow cytometric instruments. This is due to the use of electro-magnetic valves controlling the fluidics of certain instruments. This may present a problem for some instruments including BD FACScalibur range and BD FACScanto. The authors have never experienced any such problems when using BD FACScan.

\section{REAGENTS AND SOLUTIONS}

Use Milli-Q-purified water or equivalent in all recipes and protocol steps. For common stock solutions, see APPENDIX 2A; for suppliers, see SUPPLIERS APPENDIX.

\section{BSA standards}

Prepare a set of standard dilutions with BSA, starting with $500 \mu \mathrm{g} / \mathrm{ml}$, performing two-fold dilutions in PBS to $4 \mu \mathrm{g} / \mathrm{ml}$ (seven dilutions). Dispense 100- $\mu$ l aliquots of the diluted BSA standard curve solutions into microcentrifuge tubes and store up to 6 months at $-20^{\circ} \mathrm{C}$.

\section{Cell lysis buffer}

\section{$300 \mathrm{mM} \mathrm{NaCl}$}

$50 \mathrm{mM}$ Tris, $\mathrm{pH} 7.4$ (adjust $\mathrm{pH}$ of Tris base with drops of $6 \mathrm{~N} \mathrm{HCl}$ )

$0.5 \%$ Triton X-100 or NP-40

Isolation and Characterization of Exosomes

\subsubsection{4}


Glutaraldehyde, $1 \%(v / v)$

Dilute EM-grade glutaraldehyde fixatives (commercially available as $8 \%, 25 \%$ or $70 \%$ aqueous solutions; Polysciences or Sigma) in $0.1 \mathrm{M}$ sodium phosphate buffer, $\mathrm{pH} 7.4$ (APPENDIX 2A), to the appropriate dilution. Store up to 6 months at $-20^{\circ} \mathrm{C}$ or up to 1 week at $4{ }^{\circ} \mathrm{C}$ after thawing.

O.1 M PIPES or HEPES can also be used. The buffers used to prepare fixatives need to have a good buffering capacity to maintain a pH of about 7.4 during fixation.

\section{HEPES stock solution}

$2.4 \mathrm{~g} N$-2-hydroxyethylpiperazine- $N^{\prime}$-2-ethanesulfonic acid (HEPES; $20 \mathrm{mM}$ final) $300 \mathrm{H}_{2} \mathrm{O}$

Adjust $\mathrm{pH}$ to 7.4 with $10 \mathrm{~N} \mathrm{NaOH}$, added slowly

Adjust volume to $500 \mathrm{ml}$ with $\mathrm{H}_{2} \mathrm{O}$

Sterilize by passing through a $0.22-\mu \mathrm{m}$ filter

Store up to 2 years at $4^{\circ} \mathrm{C}$

\section{HEPES/sucrose stock solution}

$2.4 \mathrm{~g}$ hydroxyethylpiperazine- $N^{\prime}$-2-ethanesulfonic acid (HEPES; $20 \mathrm{mM}$ final)

$428 \mathrm{~g}$ protease-free sucrose (ICN; $2.5 \mathrm{M}$ final)

$150 \mathrm{ml} \mathrm{H}_{2} \mathrm{O}$

Adjust $\mathrm{pH}$ to 7.4 with $10 \mathrm{~N} \mathrm{NaOH}$

Adjust volume to $500 \mathrm{ml}$ with $\mathrm{H}_{2} \mathrm{O}$

Store up to 2 years at $4^{\circ} \mathrm{C}$

\section{Methyl cellulose, $2 \%(w / v)$}

Heat $196 \mathrm{ml}$ of distilled water to $90^{\circ} \mathrm{C}$ and add $4 \mathrm{~g}$ methyl cellulose (Sigma, 25 centipoise, M-6385) with stirring. Rapidly cool on ice with stirring, until the solution has reached $10^{\circ} \mathrm{C}$. Continue slow stirring overnight at $4^{\circ} \mathrm{C}$. Stop stirring and allow the solution "ripen" for 3 days at $4{ }^{\circ} \mathrm{C}$. Bring to a final volume of $200 \mathrm{ml}$ with water. Centrifuge using polycarbonate centrifuge bottles with cap assemblies $95 \mathrm{~min}$ at $100,000 \times g, 4^{\circ} \mathrm{C}$. Collect the supernatant and store up to 3 months at $4^{\circ} \mathrm{C}$.

\section{Paraformaldehyde (PFA), 2\% and 4\% (w/v)}

Dissolve $4 \mathrm{~g}$ of PFA powder (Polysciences) in $90 \mathrm{ml}$ of $0.1 \mathrm{M}$ sodium phosphate buffer (see APPENDIX 2A) and heat to $65^{\circ} \mathrm{C}$ while stirring, If needed, add drops of $1 \mathrm{~N} \mathrm{NaOH}$ until the solution becomes clear. Bring to $100 \mathrm{ml}$ with $0.1 \mathrm{M}$ sodium phosphate buffer. Cool and filter. Store at $-20^{\circ} \mathrm{C}$ in $4-$ to $10-\mathrm{ml}$ aliquots. Use thawed aliquots immediately and do not refreeze. To make $2 \%$ glutaraldehyde, dilute $4 \%$ glutaraldehyde with $0.1 \mathrm{M}$ sodium phosphate buffer.

\section{Tris/sucrose $/ \mathrm{D}_{2} \mathrm{O}$ solution}

$30 \mathrm{~g}$ protease-free sucrose

$2.4 \mathrm{~g}$ Tris base

$50 \mathrm{ml} \mathrm{D}_{2} \mathrm{O}$

Adjust $\mathrm{pH}$ to 7.4 with $10 \mathrm{~N}$ HCL drops

Adjust volume to $100 \mathrm{ml}$ with $\mathrm{D}_{2} \mathrm{O}$

Sterilize by passing through a $0.22-\mu \mathrm{m}$ filter

Store up to 2 months at $4{ }^{\circ} \mathrm{C}$ 
Uranyl acetate (4\% w/v), $\mathrm{pH} 4$

Weigh $2 \mathrm{~g}$ of uranyl acetate (Polysciences) and dissolve in $50 \mathrm{ml}$ distilled water. Store up to 4 months at $4^{\circ} \mathrm{C}$, in a 20 -ml plastic syringe protected from light. Just before use, filter the amount needed of uranyl solution with a $0.22-\mu \mathrm{m}$ filter.

CAUTION: Radioactive materials require special handling. See the institutional Radiation Safety Office for guidelines concerning proper handling and disposal.

The uranyl acetate crystals are difficult to dissolve and it may be necessary to use a rotating wheel for mixing.

\section{Uranyl-oxalate, $\mathrm{pH} 7$}

Mix 4\% uranyl acetate, $\mathrm{pH} 4$ (see recipe) with $0.15 \mathrm{M}$ solution of oxalic acid ( $0.945 \mathrm{~g}$ in $50 \mathrm{ml}$ distilled water), in a 1:1 ratio. Adjust the $\mathrm{pH}$ to 7 by adding $25 \%$ $(\mathrm{w} / \mathrm{v}) \mathrm{NH}_{4} \mathrm{OH}$ in drops to prevent formation of insoluble precipitates. Store in the dark up to 1 month at $4^{\circ} \mathrm{C}$.

\section{COMMENTARY}

\section{Background Information}

The purification of exosomes from cell culture supernatants or other biological fluids is not trivial. The most characteristic feature of exosomes that should be used both for their purification and characterization is their density. The most usual way of determining exosomes' density is on continuous sucrose gradients. A buoyant density of 1.23 to 1.16 $\mathrm{g} /$ liter, together with the presence of endocytic markers (e.g., tsg101 or alix), and images in whole-mount electron microscopy showing the characteristic cup shaped morphology are good evidence that one is dealing with exosomes. Some groups have argued that the ultrafiltration method (Lamparski et al., 2002) is less harmful and more reliable than the ultracentrifugation method described in this unit. The authors have compared the two preparation methods for the same dendritic cell supernatants side by side, using biochemical, morphological, and functional assays for exosomes. They found no significant differences. The ultrafiltration method is advisable mainly for clinical-grade applications of exosomes, because it allows rigorous control of the environment during the purification procedure.

The issue of exosome quantification also deserves some attention. Two approaches to quantifying the amount of exosomes in a given preparation have been used. One is to quantify the amount of a particulate exosomal protein using ELISA or immunoblotting. The main limitation of this approach is that it is very hard to distinguish between a modification of the number of molecules per exosome (e.g., the proportion of exosomes expressing any given marker) and a real modification in the amount of exosomes. The other approach for quanti- fying exosomes is to measure the protein concentration in the exosome preparations. In the authors' experience, if the FBS used for the production of the conditioned media is properly cleared and if one carries out the experiment carefully, the protein concentration has proven to be a reliable and reproducible approach to quantification.

Recent work on exosomes from antigenpresenting cells has caused renewed interest in this controversial field. It is the authors' feeling that the study of exosomes is now in a critical phase of scientific development. Their identity as a bone fide secreted subcellular compartment is established. The challenge for the next few years is to understand their physiological mode of action and to learn how to use them in therapeutic strategies (e.g., vaccination).

\section{Critical Parameters and Troubleshooting}

When preparing exosomes from cell culture supernatants, it is important to make sure that the cells are healthy (including no contamination with mycoplasma) and viable at the end of the exosome production period. If not, the product will be heavily contaminated with membrane fragments that are not exosomes. Fragments of apoptotic cells are bigger than exosomes when observed by whole-mount $\mathrm{EM}$, do not migrate at the proper density on sucrose gradients, and contain high amounts of nuclear proteins, such as histones (Théry et al., 2001).

When designing experiments involving exosome purification, it is important to make sure that there is an assay to characterize the preparations and show that they contain exosomes and no other contaminants. Whole-mount 
EM combined with immunoblotting is the best choice.

Aggregates of exosomes can often be observed in preparations obtained by ultracentrifugation. Resuspending the pellet in PBS containing EDTA may help, but it can also be detrimental if exosomes are subsequently used in functional assays.

Particular attention should be given to the centrifugation tubes used to prepare exosomes. Exosomal membranes may stick to some ultracentrifugation tubes, such as ultraclear tubes from Beckman (W. Stoorvogel, Faculty of Veterinary Medicine, Utrecht University, pers. comm.).

\section{Anticipated Results}

The amount of exosomes produced varies with the cell type. The authors usually obtain 0.3 to $0.5 \mu \mathrm{g}$ of exosomes per $10^{6}$ dendritic cells in $24 \mathrm{hr}$ (Segura et al., 2005). Amounts of exosomes obtained from most murine tumor cell lines (e.g., fibrosarcomas, melanomas, carcinomas) are in the same range. In contrast, very small amounts of exosomes seem to be produced by a mouse mastocytoma (P815) or thymoma (EL4; C. Théry, A. Clayton, S. Amigorena, and G. Raposo, unpub. observ.) Intestinal epithelial adenocarcinoma cell lines seem to produce slightly fewer exosomes ( $\sim 0.05 \mu \mathrm{g} / 10^{6}$ cells; Van Niel et al., 2001). Given the lack of details in the literature, it is difficult to say today whether all cell types produce exosomes and at what level, but exosome production seems to be a rather general mechanism, and an average level of production of $\sim 0.1 \mu \mathrm{g} / 10^{6}$ cells may be taken as a rough general estimate.

Purified exosomes should appear by EM as 50 - to $100-\mathrm{nm}$ vesicles surrounded by a lipid layer with a cup-shaped morphology (Fig. 3.22.2A) and exosomal proteins on their surfaces. Smaller vesicles $(<50 \mathrm{~nm})$, not displaying the cup-shaped morphology, are sometimes observed in preparations of exosomes, especially if the centrifugation is performed at $>100,000 \times g$. Such vesicles cannot be considered exosomes.

When separating 30 to $50 \mu \mathrm{g}$ of exosomal proteins on $10 \%$ or $12 \%$ SDS-gels, there should be a pattern of bands ranging from the largest to the smallest sizes, different from the pattern obtained with whole cell lysates (Fig. 3.22.2B). Be aware that exosome preparations showing mainly one band at $\sim 60 \mathrm{kDa}$ cannot be considered as good preparations because they probably contain mostly BSA from the culture medium.
Time Considerations

\section{Exosome purification}

The time required to produce cell culture conditioned medium from which exosomes will be purified is 24 to $48 \mathrm{hr}$ after the cells have reached about $70 \%$ confluency (which varies greatly with the cell type). The time required to prepare the exosome collection medium is $14 \mathrm{hr}$ (overnight). It takes $\sim 30 \mathrm{~min}$ to $1 \mathrm{hr}$ to collect the conditioned medium, depending on the number of different cells and the volume of conditioned medium. The conditioned medium can then be stored for up to a week at $4{ }^{\circ} \mathrm{C}$. From this conditioned medium, the whole procedure to purify exosomes by ultracentrifugation takes $\sim 4 \mathrm{hr}$ (Basic Protocol 1). If it has been demonstrated that Alternate Protocol can be used, the whole exosome purification procedure will take $3 \mathrm{hr}$ instead of $4 \mathrm{hr}$. For the extra sucrose-cushion step (Support Protocol 3), allow an extra 2.5 to $3 \mathrm{hr}$. To purify exosomes from viscous fluids (Basic Protocol 2) it takes $6 \mathrm{hr}$ in total. Purification of exosomes by immunoisolation (Basic Protocol 3) requires $1 \mathrm{hr}$ the first day and 45 min the next day (with a 24-hr incubation in between).

\section{Exosome analysis}

Preparation of whole-mounted exosomes for EM analysis takes a maximum of $1.5 \mathrm{hr}$. Immunohistochemical staining of exosomes for EM requires $2.5 \mathrm{hrs}$ for single labeling. If the primary antibody is not directly recognized by protein $\mathrm{A}$, an extra $1 \mathrm{hr}$ is required for the use of a bridging antibody. For double labeling the time required is doubled. Analysis of exosomes by immunoblotting takes $\sim 1 \mathrm{hr}$ to prepare the samples, plus the time required to perform SDS-PAGE followed by electrotransfer and antibody incubations; the total time varies depending on the systems used and the laboratory's preferred protocols. For exosomes analysis by FACS, it takes $2.5 \mathrm{hr}$ to prepare exosome-coated beads, followed by the time required for incubation in antibodies (30 to $60 \mathrm{~min}$ ) and flow cytometric analysis (30 $\mathrm{min}$ to $1 \mathrm{hr}$ ).

\section{Literature Cited}

Amzallag, N., Passer, B.J., Allanic, D., Segura, E., Théry, C., Goud, B., Amson, R., and Telerman, A. 2004. TSAP6 facilitates the secretion of translationally controlled tumor protein/histamine-releasing factor via a nonclassical pathway. J. Biol. Chem. 279:4610446112.

Andre, F., Schartz, N.E., Movassagh, M., Flament, C., Pautier, P., Morice, P., Pomel, C., Lhomme, C., Escudier, B., Le Chevalier, T., Tursz, T.,
Subcellular Fractionation and Isolation of Organelles

3.22.27 
Amigorena, S., Raposo, G., Angevin, E, and Zitvogel, L. 2002. Malignant effusions and immunogenic tumour-derived exosomes. Lancet 360:295-305

Andre, F., Chaput, N., Schartz, N.E., Flament, C., Aubert, N., Bernard, J., Lemonnier, F., Raposo, G., Escudier, B., Hsu, D.H., Tursz, T., Amigorena, S., Angevin, E., and Zitvogel. L. 2004. Exosomes as potent cell-free peptidebased vaccine. I. Dendritic cell-derived exosomes transfer functional MHC class I/peptide complexes to dendritic cells. J. Immunol. 172:2126-2136.

Bard, M.P., Hegmans, J.P., Hemmes, A., Luider, T.M., Willemsen, R., Severijnen, L.A., van Meerbeeck, J.P., Burgers, S.A., Hoogsteden, H.C., and Lambrecht, B.N. 2004. Proteomic analysis of exosomes isolated from human malignant pleural effusions. Am. J. Respir. Cell Mol. Biol. 31:114-121.

Blanchard, N., Lankar, D., Faure, F., Regnault, A., Dumont, C., Raposo, G., and Hivroz, C. 2002. TCR activation of human T cells induces the production of exosomes bearing the TCR/CD3/zeta complex. J. Immunol. 168:3235-3241.

Caby, M.P., Lankar, D., Vincendeau-Scherrer, C., Raposo, G., and Bonnerot, C. 2005. Exosomallike vesicles are present in human blood plasma. Int. Immunol. 17:879-887.

Clayton, A., Court, J., Navabi, H., Adams, M., Mason, M.D., Hobot, J.A., Newman, G.R., and Jasani, B. 2001. Analysis of antigen presenting cell derived exosomes, based on immunomagnetic isolation and flow cytometry. $\mathrm{J}$. Immunol. Methods 247:163-174.

de Gassart, A., Geminard, C., Fevrier, B., Raposo, G., and Vidal, M. 2003. Lipid raft-associated protein sorting in exosomes. Blood 102:43364344.

Escola, J.M., Kleijmeer, M.J., Stoorvogel, W., Griffith, J.M., Yoshie, O., and Geuze, H.J. 1998. Selective enrichment of tetraspan proteins on the internal vesicles of multivesicular endosomes and on exosomes secreted by human B-lymphocytes. J. Biol. Chem. 273:2012120127.

Fevrier, B., Vilette, D., Archer, F., Loew, D., Faigle, W., Vidal, M., Laude, H., and Raposo, G. 2004. Cells release prions in association with exosomes. Proc. Natl. Acad. Sci. U.S.A. 101:96839688.

Hegmans, J.P., Bard, M.P., Hemmes, A., Luider, T.M., Kleijmeer, M.J., Prins, J.B., Zitvogel, L., Burgers, S.A., Hoogsteden, H.C., and Lambrecht, B.N. 2004. Proteomic analysis of exosomes secreted by human mesothelioma cells. Am. J. Pathol. 164:1807-1815.

Heijnen, H.F., Schiel, A.E., Fijnheer, R., Geuze, H.J., and Sixma, J.J. 1999. Activated platelets release two types of membrane vesicles: Microvesicles by surface shedding and exosomes derived from exocytosis of multivesicular bodies and alpha-granules. Blood 94:3791-3799.

Lamparski, H.G., Metha-Damani, A., Yao, J.Y., Patel, S., Hsu, D.H., Ruegg, C., and Le Pecq,
J.B. 2002. Production and characterization of clinical grade exosomes derived from dendritic cells. J. Immunol. Methods 270:211-226.

Mears, R., Craven, R.A., Hanrahan, S., Totty, N., Upton, C., Young, S.L., Patel, P., Selby, P.J., and Banks, R.E. 2004. Proteomic analysis of melanoma-derived exosomes by twodimensional polyacrylamide gel electrophoresis and mass spectrometry. Proteomics 4:40194031.

Pan, B.T., Teng, K., Wu, C., Adam, M., and Johnstone, R.M. 1985. Electron microscopic evidence for externalization of the transferrin receptor in vesicular form in sheep reticulocytes. J. Cell Biol. 101:942-948.

Pisitkun, T., Shen, R.F., and Knepper, M.A. 2004. Identification and proteomic profiling of exosomes in human urine. Proc. Natl. Acad. Sci. U.S.A. 101:13368-13373.

Rabesandratana, H., Toutant, J.P., Reggio, H., and Vidal, M. 1998. Decay-accelerating factor (CD55) and membrane inhibitor of reactive lysis (CD59) are released within exosomes during in vitro maturation of reticulocytes. Blood 91:2573-2580.

Raposo, G., Nijman, H.W., Stoorvogel, W., Liejendekker, R., Harding, C.V., Melief, C.J., and Geuze, H.J. 1996. B lymphocytes secrete antigen-presenting vesicles. J. Exp. Med. 183:1161-1172.

Raposo, G., Kleijmeer, M.J., Posthuma, G., Slot, J.W., and Geuze, H.J. 1997. Immunogold labeling of ultrathin cryosections: Application in immunology. In Handbook of Experimental Immunology, 5th ed. (M.A. Cambridge, L.A. Herzenberg, D. Weir, L.A. Herzenberg, C. Blackwell, eds.), pp. 1-11. Blackwell Scientific, Oxford.

Segura, E., Nicco, C., Lombard, B., Véron, P., Raposo, G., Batteux, F., Amigorena, S., and Théry, C. 2005. ICAM-1 on exosomes from mature dendritic cells is critical for efficient naive $\mathrm{T}$ cell priming. Blood 106:216-223.

Skokos, D., Le Panse, S., Villa, I., Rousselle, J.C., Peronet, R., David, B., Namane, A., and Mecheri, S. 2001. Mast cell-dependent B and $\mathrm{T}$ lymphocyte activation is mediated by the secretion of immunologically active exosomes. $J$. Immunol. 166:868-876.

Théry, C., Regnault, A., Garin, J., Wolfers, J., Zitvogel, L., Ricciardi-Castagnoli, P., Raposo, G., and Amigorena, S. 1999. Molecular characterization of dendritic cell-derived exosomes. Selective accumulation of the heat shock protein hsc73. J. Cell Biol. 147:599-610.

Théry, C., Boussac, M., Veron, P., RicciardiCastagnoli, P., Raposo, G., Garin, J., and Amigorena, S. 2001. Proteomic analysis of dendritic cell-derived exosomes: A secreted subcellular compartment distinct from apoptotic vesicles. J. Immunol. 166:7309-7318.

Théry, C., Duban, L., Segura, E., Veron, P., Lantz, O., and Amigorena, S. 2002. Indirect activation of naive CD4+ T cells by dendritic cell-derived exosomes. Nat. Immunol. 3:1156-1162. 
Van Niel, G., Mallegol, J., Bevilacqua, C., Candalh, C., Brugiere, S., Tomaskovic-Crook, E., Heath, J.K., Cerf-Bensussan, N., and Heyman, M. 2003. Intestinal epithelial exosomes carry MHC class II/peptides able to inform the immune system in mice. Gut 52:1690-1697.

Van Niel, G., Raposo, G., Candalh, C., Boussac, M., Hershberg, R., Cerf-Bensussan, N., and Heyman, M. 2001. Intestinal epithelial cells secrete exosome-like vesicles. Gastroenterology 121:337-349.

Vidal, M., Mangeat, P., and Hoekstra, D. 1997. Aggregation reroutes molecules from a recycling to a vesicle-mediated secretion pathway during reticulocyte maturation. J. Cell Sci. 110:18671877.

Wolfers, J., Lozier, A., Raposo, G., Regnault, A., Théry, C., Masurier, C., Flament, C., Pouzieux, S., Faure, F., Tursz, T., Angevin, E., Amigorena, S., and Zitvogel, L. 2001. Tumor-derived exosomes are a source of shared tumor rejection antigens for CTL cross-priming. Nat. Med. 7:297-303.
Wubbolts, R., Leckie, R.S., Veenhuizen, P.T., Schwarzmann, G., Mobius, W., Hoernschemeyer, J., Slot, J.W., Geuze, H.J., and Stoorvogel, W. 2003. Proteomic and biochemical analyses of human B cell-derived exosomes. Potential implications for their function and multivesicular body formation. $J$. Biol. Chem. 278:10963-10972.

Zitvogel, L., Regnault, A., Lozier, A., Wolfers, J., Flament, C., Tenza, D., Ricciardi-Castagnoli, P., Raposo, G., and Amigorena, S. 1998. Eradication of established murine tumors using a novel cell-free vaccine: Dendritic cell-derived exosomes. Nat. Med. 4:594-600.

Contributed by Clotilde Théry, Sebastian Amigorena, and Graça Raposo

Institut Curie

Paris, France

Aled Clayton

Cardiff University

Whitchurch, Cardiff United Kingdom
Subcellular Fractionation and Isolation of Organelles

3.22.29 